DOES THE BONE MINERAL CONTENT OF

OLIGOMENORRHEIC WOMEN HAVE AN EFFE

ON BODY COMPOSITION ESTIMATIONS?

by

NAMJU LEE, B.S.

A THESIS

IN

SPORTS HEALTH

Submitted to the Graduate Faculty

of Texas Tech University in

Partial Fulfillment of

the Requirements for

the Degree of

MASTER OF SCIENCE

Approved 


\section{ACKNOWLEDGEMENTS}

$$
\begin{aligned}
& A+10-91 \leq 0 \\
& 4-16-03 \mathrm{sm}
\end{aligned}
$$

no. 106

Cop. 2

I wish to express appreciation to those who have supported me and

encouraged me. Particularly. I would like to acknowledge my debt to following persons.

I would like to give a special word of thanks to Dr. Jacalyn McComb. my thesis committee chair as well as my advisor. I really appreciate her support and encouragement. I enjoyed working with her. I was honored to have her as my advisor. I also would like to express my thanks to Dr. Williams and Dr. Norman for serving my thesis committee. Their helpful suggestions and supports made this project perfect.

I am grateful to Texas Tech University for awarding me a Summer Thesis Research Award. The money was used to cover expenses associated with the gathering of the data. I would like to say thanks to Dimensions for Women`s Health. UMC. They helped me to have a DEXA scan for all participants.

Last but not least, I would like to thank my parents, Sang-hyo Lee and Soon-ja Lee who have supported me to make my degree a reality. And I thank all my sisters, Sung-hee, Sung-eun, and Sung-shin. Even though all my family lives in Korea. they always love me and support me. I miss all of them. Especially, I want to thank my little sister, Soo-won, who lives with me in the States.

In addition. I thank my best friends who have encouraged me a lot. I would like to say thanks to Dr. Ju-rip Lee who was my advisor in Korea, and he encouraged me to study in the States. I could have never made my degree without all of you. 


\section{TABLES OF CONTENTS}

ACKNOWLEDGEMENTS $\quad$ ii

ABSTRACT Vi

LIST OF TABLES Viii

CHAPTER

I. INTRODUCTION 1

Statement of Problem 3

Hypothesis +4

Operational Definitions

$\begin{array}{ll}\text { Delimitations } & 6\end{array}$

$\begin{array}{ll}\text { Risk Factors } & 6\end{array}$

$\begin{array}{ll}\text { Significance of the Study } & 7\end{array}$

II. REVIEW OF LITERATURE $\quad 8$

$\begin{array}{ll}\text { Oligomenorrhea } & 8\end{array}$

$\begin{array}{ll}\text { Bone Density } & 12\end{array}$

Two-Component Model and Multi-Component Model 16

$\begin{array}{lr}\text { Bone Mineral Density Assessment } & 19\end{array}$

III. METHODOLOGY 22

Selection of the Participants 22

Instrumentation 22

Procedure 24 
IV. STATISTICS AND RESULTS 29

$\begin{array}{ll}\text { Statistical Analysis and Results } & 29\end{array}$

V. DISCUSSION AND CONCLUSIONS 37

$\begin{array}{ll}\text { Discussion } & 37\end{array}$

Conclusions +4

Suggestions for Further Research

BIBLIOGRAPHY

APPENDICES

A. SCRIPT TO BE USED TO RECRUIT VOLUNTEERS FOR THIS STUDY 50

B. CONSENT FORM 52

C. WOMEN'S HEALTH HISTORYQUESTIONNAIRE 55

D. BODY COMPOSITION DATA COLLECTING SHEET 60

E. PULMONARY DATA COLLECTING SHEET 62

F. SKINFOLD DATA COLLECTING SHEET 64

G. WATER DENSITY FOR VARIOUS WATER TEMPERATURES 66

H. WATER VAPOR PRESSURES OF SATURATED AIR AT VARIOUS TEMPERATURES $\quad 68$

I. REPEATED ONE-WAY ANALYSIS OF VARIANCE 70

J. PAIRED SAMPLE T-TEST 72

K. RELATIONSHIP OF Db WITH BMD. BMIC. 2-COMP(O.NINI.
AND 3-COMPONENT MODEI.S

L. REPEATED NE ISUREMENTS WITH 6 LEVEI.S 76 
M. PAIRED SAMPLE T-TEST WITH 6 LEVELS 


\begin{abstract}
The purpose of this study was to determine if the bone mineral content (BMC) of oligomenorrheic women is altered to an extent that differences would be obtained in the body composition estimations between 2- and 3-component models. The twocomponent models used to answer this research question were: (a) 7-site skinfolds (SKF) to determine body density ( $\mathrm{Db}$ ) and Siri's equation to determine body composition; and (b) hydrostatic weighing to determine $\mathrm{Db}$ and Siri`s equation to determine body composition. The three-component models included: (a) hydrostatic weighing to determine $\mathrm{Db}, \mathrm{BMC}$ as measured by the dual energy $\mathrm{x}$-ray absorptiometry (DEXA), and Lohman's 3-component mineral density equation to determine body composition; and (b) the DEXA Lunar DPX IQ 5006 scan. Twohundred and eighty-nine participants completed the Women`s Health Questionnaire for screening prior to inclusion in the study. Study participants included 10
\end{abstract} oligomenorrheic females (age $=20.70 \pm 2.67 \mathrm{yr}$, height $=162.05 \pm 5.38 \mathrm{~cm}$, weight $=$ $57.36 \pm 9.36 \mathrm{~kg}$ ). Descriptive statistics and a repeated one-way analysis of variance (ANOVA) were conducted to test for significant differences between four different methods of body composition assessment. There was a significant difference among the models $(F(3,27)=26.89, p<.05)$. Follow-up paired t-tests between Lohman`s 3-component mineral density model and Siri's 2-component model revealed a significant difference in body composition results, $t(9)=8.6+7, p<.05$. This would lead one to conclude that the mineral density of this population has an effect on body composition estimations. However, there was also a significant difference between the 
2-component models and between the 3-component models. Based on the results of this study. it seems that the method and equation chosen has the greatest impact on body composition estimations rather than the number of components included in the model. 


\section{LIST OF TABLES}

4.1 Group Descriptive Statistics of Participants

4.2 Individual Descriptive Statistics of Participants

4.3 Physical Characteristics of Participants

4.4 Activities of Participants

4.5 Participants ${ }^{`}$ Health History

G.1 Water Density for Various Water Temperatures

67

H.1 Water Vapor Pressures of Saturated Air at Various Temperatures

I.1 Repeated One-Way Analysis of Variance

J.1 Paired Sample T-Test

K.1 Relationship of Db with BMD. BMC. 2-Component, and 3-Component Models

L.1 Repeated Measurements with 6 Levels

M. Paired Sample T-Test with 6 Levels 


\section{CHAPTER I}

\section{INTRODUCTION}

Today, more than ever, young athletic females are at a risk for the development of one or more of a triad of medical disorders that include disordered eating. amenorrhea, and osteoporosis. This triad occurs not only in elite athletes but also in physically active women participating in a wide range of physical activities. Numerous studies have linked disordered eating and intense exercise to menstrual cycle disturbances, particularly in women who participate in endurance type sports or in sports where body fat (BF) is maintained at a low level (Drinkwater. Bruemner, \& Chesnut, 1990). Women who participate in endurance type sports and who have irregular menstrual cycles also have decreased BF (Calabrese et al., 1983; Carlberg, Buckman, Peake. \& Riedesel, 1983). Research has shown that the BF of oligo/amenorrheic women is less $(16.9 \%)$ than that of eumenorrheic women (20-29\%). Female college athletes and women who train intensively are at risk for the development of menstrual disorders and loss of bone mineral density (BMD) (Drinkwater et al.. 1984; Frisch et al., 1981). When normal reproductive hormonal mechanisms are disturbed. bone metabolism may be altered (Linnell, Stager. Blue, Oyster, \& Robertshaw. 1984: Snow-Harter \& Marcus, 1991). Bone remodeling responds to mechanical stress. hormonal alterations, and nutritional status. When estrogen levels are low, bone resorption increases, and bone formation and density decrease resulting in osteoporosis.

Field regression equations have been developed for the general population to estimate body composition based on the 2-component model of body composition 
assessment. The 2-component model of body composition divides the body into a fat component and fat-free body (FFB) component. The FFB component consists of all residual chemicals and tissues including water, muscle (protein), and bone (mineral).

Additionally. tables can be found in fitness centers, lab manuals. and athletic settings that estimate body composition based on skinfold thickness. These tables have also been developed from the 2-component model and generally use Siri`s equation to estimate body composition (Jackson, Pollock, \& Ward, 1980). As previously stated. the 2-component model for body composition assessment is commonly used for the general population. However, for this model to be valid, certain assumptions must be met.

1. The density of fat is $0.901 \mathrm{~g} / \mathrm{cc}$.

2. The density of FFB component is $1.100 \mathrm{~g} / \mathrm{cc}$.

3. The densities of fat and the FFB components (water, protein, mineral) are the same for all individuals.

4. The densities of various tissues comprising the FFB are constant within an individual, and their proportional contribution to the lean component remains constant.

5. The individual being measured differs from the reference body only in the amount of fat; the FFB component of the reference body is assumed to be $73.8 \%$ water. $19.4 \%$ protein, and $6.8 \%$ mineral.

This may not be an appropriate assumption for women who have altered menstrual cycles and decreased bone density. Research has shown that women who are oligomenorrheic have decreased bone density (Baker \& Demers, 1988; Barrow \& Saha. 
1988; Buchnan, Bitzer, Waldman, \& Ford, 1987; Cann, Martin, Genant. \& Jaffe. 1984:

Drinkwater et al., 1990). Howat, Carbo, Mills, and Wozniak (1989) found that

oligo/amenorrheic women's mean bone density was $1.17 \pm 0.03 \mathrm{mg} / \mathrm{cm}^{2}$ (regular $1.37 \pm$

$0.04 \mathrm{mg} / \mathrm{cm}^{2}$ ). Cann et al. (1984) also found that spinal bone mass is decreased

approximately $22 \%$ to $29 \%$ from normal values in amenorrheic women.

Significantly decreased bone density in a female athlete would cause an overestimation of BF when using the 2-component model (Lohman, 1992). This overestimation of BF may increase the anxiety of young athletic females who are already pre-occupied with the idea of thinness and thus contribute further to the cycle of amenorrhea, disordered eating, and osteoporosis. At the other end of the spectrum. the risks associated with decreased body composition may not be evident to coaches and health care providers because of an overestimation of BF. Therefore, it may be necessary to use a multi-component model. which measures the variable in question for a specific population. The 3-component model accounts for densities of tissues within a population that may differ from the reference person, such as BMC. If women who are oligomenorrheic have significantly decreased bone density, this variable needs to be accounted for when assessing body composition.

\section{Statement of Problem}

The purpose of this research project is to determine if the $\mathrm{BMC}$ of oligomenorrheic women significantly alters body composition estimations. More specifically. $w$ ill there be a difference in body composition estimations when using 2-component models. which do 
not account for variation from the reference person in BMC, and the 3-component models which account for variations in BMC for that particular population? The 2-component models used to address this research question will be Siri's equation using either 7-site skinfolds (SKF) or hydrostatic weighing (HW) to estimate Db. Lohman`s bone mineral density equation using $\mathrm{HW}$ to measure $\mathrm{Db}$ and the Lunar DEXA Scan to measure BMC will be one of the 3-component models used. The Lunar DEXA Scan using BMC as the third variable to determine body composition will be the other 3-component model used. DEXA analyzes both BMC and the soft tissue surrounding the bone and measures the amount of fat and fat-free tissue.

The purpose of using more than 1 equation for the 2-component model and the 3component model is to provide additional reliability and validity to the findings.

\section{Hypothesis}

There are null hypothesis and research hypothesis in this study.

1. Null Hypothesis:

The bone mineral content of oligomenorrheic active women will not have an effect on body composition estimations for this particular population. Specifically. there will be no difference between 2-component models and 3-component models when bone mineral content is accounted for in the model.

2. Research Hypothesis:

The bone mineral content of oligomenorrheic active women will have an effect on body composition estimations for this particular population. Specifically, there 
will be a difference between the 2-component models and 3-component models when bone mineral content is accounted for in the model.

\section{Operational Definitions}

Universally accepted definitions of various menstrual patterns are lacking. The definitions used in this study are consistent with those used in studies of large populations of women. For the purpose of clarification, the following definitions of terms are given.

Eumenorrheic For the purpose of this study the terms eumenorrheic, regular, and cyclic will be used interchangeably to refer to women whose menstrual cycles occur consistently at intervals from 25 to 38 days (Loucks \& Horvath, 1985).

Oligomenorrheic For the purpose of this study the terms oligomenorrheic and irregular will be used interchangeably to refer to women whose menstrual cycles occur inconsistently at intervals from 39 to 90 days (Loucks et al., 1985).

Amenorrheic The terms Amenorrheic and acyclic will be used interchangeably to refer to women whose menstrual cycles occur at intervals greater than 90 days (Loucks et al., 1985). Amenorrhea can be defined as either primary (absence of menarche by age 16) or secondary (absence of menstrual function for 6 consecutive times after normal menarche has occurred).

Active women Women who exercise regularly at least 4 days per week for 45 minutes (Drinkwater et al., 1990). 


\section{$\underline{\text { Delimitations }}$}

This study makes the following delimitations.

1. Participation is limited to women who live in Lubbock or the surrounding area.

2. Participation is limited to women who meet the following criteria for inclusion in the study.

a. Participants must be oligomenorrheic as determined from a menstrual history questionnaire.

b. Participants must not be pregnant as determined from a urine test.

c. Participants must not have used oral contraceptives for the past 6 months as determined form the menstrual history questionnaire.

d. Participants must not have medical problems affecting bone mineral metabolism as determined from the menstrual history questionnaire.

e. Participants must be nonsmokers.

f. Participants must exercise at least 45 minutes a day 4 times a week.

\section{$\underline{\text { Risk Factors }}$}

This study has following risk factors.

1. Completion of the Health Questionnaire may cause some women to recognize potential existing health problems, which may create some stress.

2. Hydrostatic weighing may increase the anxiety in a participant because of holding one's breath underwater.

3. The DEXA scan may pose a physical risk to participants who are pregnant. 


\section{Significance of the Study}

Information from this study may establish the need for body composition prediction equations for oligomenorrheic women using the 3-component model. If the bone density levels of these women are significantly altered to impact body composition assessments, this new information will provide the foundation for future study in this area. Accurate regression equations will enable health care professionals to more accurately determine body composition values of active women with menstrual disorders and therefore develop more appropriate treatment options. This study will also benefit the participants involved by providing information about their current BMD and BF levels at no cost to the subject. 


\section{CHAPTER II}

\section{REVIEW OF LITERATURE}

Research findings concerning decreased BMD for oligomenorrheic women will be highlighted initially in this review as well as the terminology used to differentiate menstrual dysfunctions. Secondly, bone density and factors contributing to bone density will be discussed. Lastly, body composition equation models and bone mineral density assessment will be discussed.

\section{Oligomenorrhea}

Variation in the definition of menstrual dysfunction exists between what is considered normal or eumenorrheic and what is considered abnormal or oligomenorrheic and amenorrheic. The definitions of menstrual dysfunction are somewhat difficult to compare among research findings. In the research literature. eumenorrhea is normal menstrual function and has been defined as follows: (a) menses with intervals of 23 to 33 days, with a duration of 3 to 7 days (Scott, Disaia, Hammond, \& Spellacy, 1984): (b) 10 to 13 menses a year (Barrow et al., 1988; Drinkwater et al., 1990); (c) regular menses at least every 35 days (Lutter \& Cushman, 1982); and (d) menstrual cycles between 23 to 35 days in length with menstrual flow from 4 to 6 days (Carlberg et al.. 1983).

Oligomenorrhea has been defined as irregular menstrual cycles according to the following criteria: (a) missing 1 to 4 cycles a year (Barrow et al.. 1988; Dale. (ierlach. \& Wilhite. 1979); (b) irregular menses every 36 days or longer (Lutter et al.. 1982: Nattiv. 
Agostini. Drinkwater, \& Yeager. 1994); (c) cycles with intervals of 35 to 90 days (Bachmann \& Kemmann, 1982: Loucks et al.. 1985): and (d) menses at intervals greater than 40 days and usually irregular (Scott et al., 1984): and (e) no menstrual periods during the previous 3 months or 4 or fewer periods per year (Calberg et al., 1983). Amenorrhea has been defined as: (a) menses every 3 months (Barrow et al.. 1988: Bachmann et al.. 1982; Dale et al.. 1979; Singh, 1981); (b) no more than 1 menstruation in the preceding 12 months (Drinkwater et al.. 1984): (c) the absence of menses in the preceding year (Lutter et al.. 1982): (d) absence of menses for greater than 90 days (Calabrese et al.. 1983): and (e) a six-month interval between cycles and irregular cycles differing in length by 9 or more days (Frisch et al.. 1981).

\section{Menstrual Dysfunction - Multifunctional Factors}

A variety of associated factors has been proposed to cause of menstrual dysfunction and some combination of these associated factors synergistically affects the reproductive system (Loucks et al.. 1985). Linnell et al. (1984) stated that causes of changes in menstrual frequency are decreased hypothalamic activity, early pubertal athletic training, low body fatness, and elerated prolactin and endogenous endorphin levels. Other researches have stated that menstrual dysfunction is associated with significant weight loss, decreased BF-to-lean mass ratio, stress, age of sports participants. intensity of athletic training. and the sudden initiation of high volume aerobic training (Baker et al.. 1988: Barrow et al.. 1988: Caranaugh. Kanochoff. \& Bartels, 1989: I.oucks. 1990; Singh, 1981). According to Bachmann et al. (1982) and Barrow et al. (1988). pregnancy history, use of oral contraceptives, the incidence of weight gain. history of 
perceived emotional turmoil. excessive mental and physical work loads, and sports activity could be factors that affect menstrual cycles. It has been suggested that menstrual irregularities in athletes are related to low body weight and low BF due to the significant weight loss and energetic sports activity (Carlberg et al., 1983; Speroff \& Redwine, 1980).

\section{$\underline{\text { Hormonal Status }}$}

The normal hormone changes throughout the menstrual cycle are depicted in Figure 2.1.

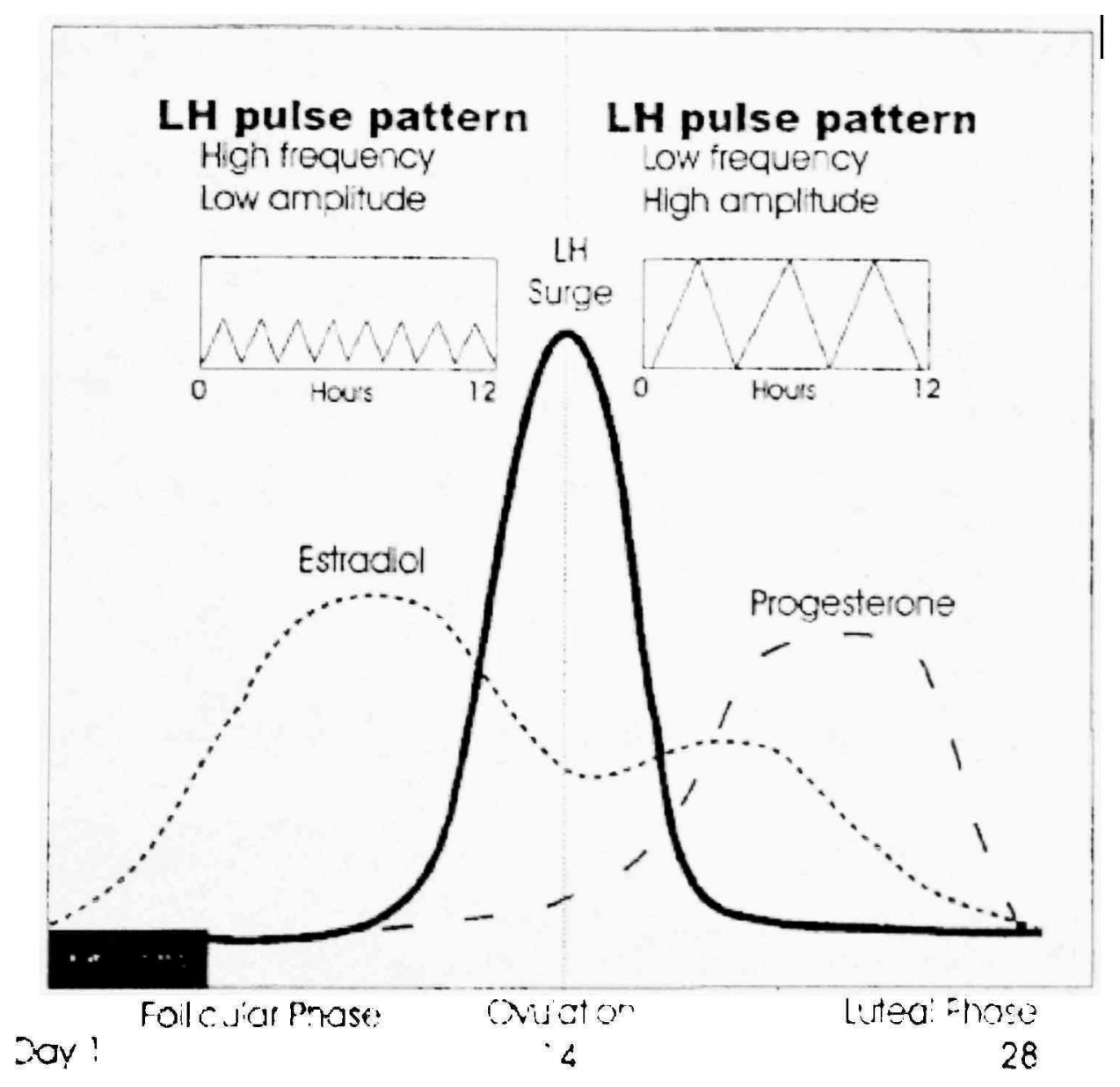

Figure 2.1 Patterns of Hormone Secretion Across the Normal Menstrual Cycle An LH surge occurs at the time of ovulation and marks the division between the follicular phase (Dans 114 ) and the luteal phase (Days 15-28). LH pulse pattern also changes across the menstrual cycle; pulse frequency decreases from the follicular phase $(\sim 65-$ to 80 -min intervals) to the luteal phase $(\sim 185-10200$ - 
min intervals), whereas pulse amplitude increases from the follicular phase $(-5 \mathrm{mlU} / \mathrm{mIL})$ to the luteal phase $(\sim 12 \mathrm{mlU} / \mathrm{mL})$ (Harbor, 1999).

Estradiol concentration is decreased in response to exercise (Adami et al.. 1998;

Bullen et al.. 1985; Loucks et al., 1985). Menstrual dysfunction results from lowered estrogen levels in athletic women, which can lead to a decrease in bone mass (Clarkson $\&$ Haymes, 1995). Low estradiol concentrations are suggestive of a lack of ovarian follicular development. Nelson et al. (1986) stated that the average estradiol concentration in the amenorrheic women is only one-third of the level found in the eumenorrheic women during the early follicular phase. Also. Drinkwater et al. (1984) found that estradiol levels are significantly lower in the amenorrheic women. Therefore, estradiol levels are of essential importance in evaluating menstrual dysfunction.

In menstrual dysfunction, the pattern of estrogen and progesterone shows no phasic elevations indicating anovulation with no follicular or luteal development. This ovarian suppression is due to reduced frequency and regularity in the pulsatile secretion of luteinizing hormone (Loucks et al., 1985). Delayed menses and loss of luteinizing hormone surge occurs more frequently in the weight loss women (Bachmann ct al.. 1982: Bullen et al., 1985; Harber, 1999). The high incidence of anorulation and luteal disorders also occurs in this group (Bullen et al.. 1985).

Circulating estrogens have an effect on the maintenance of bone composition by affecting the bone remodeling process via direct and indirect mechanisms. Bone mineral loss has been reported in young women with low estrogen concentrations. This suggests a major role for estrogens in the prevention of accelerated bone loss (Lloyd et al.. 1986: 
Loucks et al.. 1985; Bemben \& Fetters. 2000). Cann et al. (1984) concluded that the combination of deceased estrone and estradiol production in some women may lead to amenorrhea and loss of estrogen's bone protection effect. Extreme weight-bearing exercise partially overcomes the effects of estrogen deprivation (Marcus et al.. 1985).

\section{Bone Density}

Bone is continuously undergoing the coupled processes of resorption and formation. These processes are important for maintenance of bone mass. Bone hypertrophy occurs when stress is applied in excess of normal levels. Osteoblastic activity exceeds osteoclastic resorption, which leads to a net gain in bone. Snow-Harter and Marcus (1991) suggested that stress-related osteonal fatigue damage stimulates the remodeling process. Bone formation is encouraged by weight bearing activity and hormonal influences such as estrogen, androgen, growth hormone. and thyroid hormones. Excluding articulator cartilage and growth plate, normal growing bones can adapt their architecture to persistent underloading and repeated overloading by different biologic mechanisms (Frost. 1990; Nelson et al., 1986).

Net loss occurs when resorption is greater than formation. A negative balance between bone resorption and formation is the basis of many bone diseases (Bemben. 1999: Rodan, 1992). 
Bone Density and Menstrual Dysfunction

Bone is gained during adolescence, reaches a plateau level during the third decade of life, and remains stable until approximately age 50 , after which progressive. gradual loss is observed. The prevalence of osteoporosis increases with age and the initial loss of bone at age 50 is temporarily more rapid in women because of menopause (Kaplan, 1985). Bone density may be influenced by variables such as current menstrual status. menstrual history, body mass, functional loading, and calcium balance.

Body weight is a significant predictor for bone density. There are three possible explanations for this relationship: (a) body weight is representative of body size. and larger women have a greater bone mass; (b) the skeleton responds to the greater mechanical stress by increasing mass; and (c) there is the increased conversion of androgens to estrogens in the adipose tissue of the heavier women (Drinkwater et al.. 1990).

Linnell et al. (1984) found that there is a relationship between ovarian function and bone density in amenorrheic athletes. Previous studies of oligomenorrheic and eumenorrheic athletes examined BMD at the lumbar vertebrae and the shaft of radius (Drinkwater et al.. 1990). Researchers found decreased BMD at the lumbar and radius sites. Explanations for the decrease in bone density in this population are: (a) training errors (Barrow et al., 1988); (b) the hypoestrogenic status affects trabecular. not cortical. bone (Drinkwater et al., 1990); and (c) the active life-style of the amenorrheic women attenuates bone loss at the appendicular sites (Drinkwater et al., 1990). Cann et al. (1984) also found that amenorrhea is associated with decreased spinal bone mass. Women $w$ ith 
oligomenorrhea and amenorrhea are at risk for losing bone mass. The combination of excessive thinness and amenorrhea may affect female athletes by reducing bone mass (Drinkwater et al., 1990). Menstrual dysfunction and decreased bone density have been found to be related (Buchnan et al., 1987). Oligomenorrheic women athletes have a lower BMD compared to normal women, particularly the lumbar spine (Drinkwater et al.. 1984: Salamon et al., 1998). Menstrual dysfunction is accompanied by a decrease in bone density in women (Barrow et al.. 1988). Decreased bone density is more serious for women with a low body weight (Adami et al., 1998; Drinkwater et al.. 1990; Parazzini et al., 1996). Amenorrheic athletes have decreased bone density and a high risk of stress fractures (Baker et al.. 1988; Barrow et al., 1988).

\section{Physical Activity and Bone Metabolism}

The skeleton is constantly subjected to external ground reaction forces and forces generated by muscle contraction. These forces lead to alterations in bone shape and to a large degree, determine its strength. All forces imposed on bone produce strain of some magnitude. Loading creates stress within a bone, which may stimulate either external or internal remodeling, or both, and can lead to a change in shape and in dimension. When the strain is greater, the probability of damage and failure is higher (Frost, 1990).

The goal of bone development is to provide a structure or framework for the body that allows efficient locomotion with an appropriate level of bone mass to resist fracture (Dalsky, 1990). Regular weight bearing or bone stressing exercise is essential for maintaining bone mass. When the stress is applied to bone, the tissue responds by 
increasing in mass, density, and structural properties (Bemben, 1999; Drinkwater et al.. 1984).

Bone mass is maintained at appropriate levels to afford structural competence for functional loading. Mechanical loading of the skeleton during weight-bearing exercise causes a strain or deformation of the bone. A negative response is seen with lack of physical activity or a lack of mechanical loading and is associated with resorption, resulting in a net loss in bone mass. The positive influence of exercise on bone can be attenuated by environmental conditions including the hormone and nutritional status of an individual. The positive adaptations of bone to physical activity can be reduced if the environmental conditions for bone promote greater resorption than formation (Dalsk!. 1990).

Kaplan (1985) states that mechanical loading through physical exercise is a positive influence on BMD. Physical exercise contributes to a greater than normal bone mass. A lack of physical activity has a negative influence on BMD. An absence of mechanical loading contributes to the net loss of bone mass. This has been demonstrated in studies of prolonged immobilized weakness, and bed rest. The rates of bone loss are primarily a result of an increase in resorption unmatched by formation. Internal forces are created by muscle contraction; external forces are imposed by the gravitational field (static) and by weight bearing (dynamic).

According to Frost (1990). if accumulated strain remains constant, bone will persist in an equilibrium state. If strain decreases, bone is lost until a new equilibrium is reached. An optimal level of strain is necessary to maintain bone mass, and the bone 
mass is well correlated with functional loading. Increasing the number of load cycles results in no additional increase in bone mass. Applied to exercise training. this theory predicts that exercise such as weight training, in which load is increased, will be more effective in improving bone mass.

Weight-bearing exercise and estrogen levels are considered to be major factors affecting bone density in women. However, exercise does not seem to increase BMD in women with menstrual dysfunction, although weight-bearing exercise has been reported to increase bone density. Menstrual dysfunction may lower bone density. in spite of physical activity (Howat et al., 1989). The amount of physical activity reported by amenorrheic women does not protect them from a loss of vertebral bone mass. This suggests that the value of exercise does not maintain skeletal integrity in this group of women (Drinkwater et al., 1984). Exercise, especially jogging and distance running. increases the rate of oligomenorrhea from about from $5 \%$ to $20 \%$ of women who exercise regularly and vigorously (Bachmann et al.. 1982: Barrow et al., 1988: Lloyd et al.. 1986). Recent studies state a positive correlation between intensive exercise and menstrual dysfunction.

\section{Two-Component and Multi-Component Models}

This review addresses the assumptions of the 2-component and 3-component models used in estimating body composition values and also decreased BMID. 


\section{$\underline{\text { Two-Component Models }}$}

The 2-component model of body composition divides the body into a fat component and a FFB component. The FFB component consists of all residual chemicals and tissues including water. muscle (protein). and bone (mineral). The 2-component model of body composition makes the assumption that the individual being measured differs from the reference body only in the amount of fat; the free-fat component of the reference body is assumed to be $73.8 \%$ water. $19.4 \%$ protein, and $6.8 \%$ mineral. This may not be an appropriate assumption for women who have altered menstrual cycles and decreased bone density. Research has shown that women who are oligomenorrheic have decreased bone density (Baker et al.. 1988: Barrow et al.. 1988; Buchnan et al.. 1987: Cann et al., 1984: Drinkwater et al., 1990).

Generally, the 2-component model equations provide accurate estimates of $\% \mathrm{BF}$ as long as the basic assumptions of the model are met, and have served as the foundation upon which the HW method is based. However, there are no guarantees that the FFB composition of an individual within a certain population subgroup will exactly match the values assumed for the reference body. FFB density varies with age. gender, ethnicity, level of body fatness, and physical activity level. and depends mainly on the relative proportion of water and mineral comprising the FFB component (Lohman. 1984). The 2component model is commonly used for general population. This indirect method measuring body composition separates the body into a fat component and a FFB component (Clark. Kuta, \& Sulivan. 1992). 
However, limitations of the 2-component model are the variations in the fat-free compositional differences among populations (Lohman, 1984). Using assumed proportions of water, mineral, and protein and their respective densities: equations were derived to convert the individual's $\mathrm{Db}$ from HW with the 2-component model into relative body fat proportions (\%BF). The most commonly used equation is Siri's (1961) equation, $\% \mathrm{BF}=(4.95 / \mathrm{Db}-4.50) \times 100$. The FFB component is obtained as $\mathrm{FFB}=$ body weight - (\% fat/100). However, the validity of such equations relies on the assumption that for each population studied the fat-free body composition is similar (Lohman, 1984).

\section{Multi-Component Models}

Researchers have applied multi-component models of body composition based on measured total body water and bone mineral values. This approach can avoid systematic errors in estimating BF by replacing the reference man with population-specific bodies that take into account the age, gender. and ethnicity of the individual. The multicomponent model predicts body fatness utilizing the variables $\mathrm{Db}$, body water content. and mineral content of the body. This model analyzes variations in the FFB component from hydration and BMC. The use of the multi-component model enables the researcher to evaluate assumptions in the FFB component such as altered BMD or body water content. This model can be used to access body composition more accurately and be applied to several populations (Clark et al., 1993; Lohman, 1984). A multi-component model can adjust the proportions and densities of each of the subcomponents of the FFB 
component, and yield more appropriate population-specific equations to convert the $\mathrm{Db}$ to \% BF (Bunt et al., 1989). Lohman's equation has been developed for specific populations that may have altered bone density. Lohman's equation is as follows: $\%$ fat $=$ $[6.386 /(\mathrm{Db})+3.961 / \mathrm{m}$ (mineral as a fraction of body weight $)-6.090] \times 100$ (Bunt et al.. 1989; Lohman, 1984). Therefore, new equations will be developed for various populations, which will enable more accurate estimations of fat content from Db.

\section{Bone Mineral Density Assessment}

Technical developments have resulted in reliable methods for the quantitative assessment of the skeleton. Accurate, noninvasive measurement of bone mass emerged with the development of photon absorptiometry and computed tomography (CT). The method has high reproducibility and has been used to estimate bone mineral changes (Lohman, 1984).

\section{Computed Tomography}

Computed Tomography (CT) frequently has been used to determine trabecular bone density of the lumbar spine. CT measures trabecular bone only. avoiding areas of aortic calcification. Trans-iliac bone biopsy is an invasive technique that provides a core sample of largely trabecular bone bordered by internal and external cortices. Recent applications of this technique also permit assessment of the degree to which trabecular elements are connected to each other, and the magnitude of spaces between adjacent 
connectivity of trabecular bone (Clarkson et al., 1995; Hassager \& Christiansen. 1994; Lukaski, 1987).

\section{Single Photon Absorptiometry}

Single photon absorptiometry (SPA) is based on the attenuation of a collimated photon beam by bone. The measurements are accurate, precise and suited to regions of the body in which variations in soft tissue composition. (Hassger et al., 1994: SnowHarter et al., 1991). This can be used and accepted for investigation of local and regional bone measurement, usually the radius and the ulna. Local BMC can be measured with either the axial or appendicular skeleton (Lukasiki, 1987). Thus, it is not desirable to use SPA for measuring total body BMC.

\section{Dual Photon Absorptiometry}

Isotopes that emit photons permit application of the photon absorptiometry principle to the central skeleton, most often the lumbar spine and proximal end of the femur. Current dual photon absorptiometry (DPA) machines employ gadolinium-153 (Davee, Rosen, \& Alder, 1990). DPA has been used for measuring regional BMD particularly spine and femur. The advantages of using DPA are precise method of quantifying total body and regional skeletal and soft tissue components of body, low radiation dose, and total body determination of bone mineral and lean body mass by direct analysis (Lukaski. 1987; Mazess, Barden. Bisek, \& Hanson. 1990): Verloo!. Dequeker, Gensens, Nijs, \& Gons, 1991). 


\section{Dual Energy X-Ray Absorptiometry}

Dual energy x-ray absorptiometry (DEXA) has been developed from DP.A. DEXA is now commonly used for estimating body composition (Jebb, Goldberg. \& Elia. 1993). The relationship between bone mineral and total body mineral is important, and accurate estimates of total body mineral estimates are provided by DEXA. DEXA uses a dual energy $\mathrm{x}$-ray beam and its radiation exposure is much lower $(<5 \mathrm{mRem})$ than that from SPA (15mRem) and CT (100-1000mRem). For total body scans, the medium scan mode ensures up to a $100 \mathrm{~kg}$ body mass and a ratio less than 0.7214 of weight/stature (Wellens, Roche, Guo, Chumlea, \& Siervogel, 1993). The DEXA method permits a more precise measurement of body composition than DPA with much faster determinations (Bemben, 1999; Davee et al., 1990; Mazess et al.. 1990).

DEXA has been considered an accurate and precise technique for measuring total and regional body composition (Wellens et al., 1993). DEXA can measure any area of interest in the body. DEXA can be used to estimate BMD and may be also useful to estimate soft tissue composition (Clarkson et al.. 1995; Hansen et al.. 1993; Hassager et al., 1994). DEXA analyzes both BMC and the soft tissue surrounding the bone and measures the amount of fat and fat-free tissue (Clark et al., 1993). 


\section{CHAPTER III}

\section{METHODOLOGY}

\section{Selection of the Participants}

Participants were recruited from recreational fitness centers and athletic settings at Texas Tech University (TTU) and the surrounding Lubbock area (see Appendix A). To be eligible for this study, participants must meet the following criteria: (a) participants must be oligomenorrhea (women whose menstrual cycles occur inconsistently at intervals from 39-90 days) for at least 6 months; (b) participants must not have a history of oral contraceptive, hormone or steroid use for at least 6 months or cumulative use of over 6 months (Lloyd et al.. 1987); (c) they must not be pregnant or have had a history of hysterectomy, endocrine diseases, or have medical problems affecting bone mineral metabolism; (d) participants must be nonsmokers; and (e) participants must exercise at least 4 times a week for 45 minutes a day.

\section{$\underline{\text { Instrumentation }}$}

Human Subjects Consent Form: Prior to the collection of any data, participants were asked to complete the consent form (see Appendix B).

\section{Women's Health History Questionnaire}

Participants were asked to complete a women's health history questionnaire in order to screen for criteria for inclusion in the study (see Appendix C). 


\section{Bone Mineral Content and Bone Density}

Total body DEXA scan was performed to measure BMD. Selected participants went to the University Medical Center (UMC) to have a bone scan using the Lunar DPX IQ \#5006 DEXA scan. The bone scan was conducted at Dimensions Center for Women's Health, UMC, 602 Indiana Avenue; Lubbock, TX 79415: (806) 743-4377.

\section{$\underline{\text { Seven-Site Skinfolds }}$}

Seven-site skinfolds testing was used to assess the accuracy of the HW measurements. There is a possibility when performing underwater measurements that the individual may not expire to residual volume prior to total immersion. This would increase their estimation of BF depending on the amount of air remaining in the lungs. The standard error for SKF is estimated to be $\sim 5 \% \mathrm{BF}$; depending on the prediction equation and the sample of subjects, some reported errors have ranged from 3 to $9 \% \mathrm{BF}$ (Lukaski. 1987). Skinfold measurements were taken using a Lange caliper. Skinfold measurements were taken at seven sites: chest, axillary, triceps, subscapular, abdomen. suprailiac, and thigh (Lohman, 1981, 1982). Lohman (1992) stated that the various sources of error in SKF \% fat could include skinfold measurement technique, skinfold location, caliper, and compressibility of skinfold. Therefore, percent error in skinfold is usually higher than HW. 


\section{Hydrostatic Weighing}

Instrumentation for HW includes a tank $(128 \mathrm{~cm}$ in diameter and $402 \mathrm{~cm}$ in circumference), water maintained at $36^{\circ} \mathrm{C}$ to $39^{\circ} \mathrm{C}$, a scale, a chair. and a weighted belt. A Metler Analytical Scale was used to measure the density of water in order to validate reference norms for the water in this region.

\section{Residual Lung Volume}

Residual lung volume (RV) was determined from the closed circuit oxygen dilution method (Wilmore, 1980). Equipment needed for this procedure include: a threeway breathing valve with a mouthpiece, a small $(5 \mathrm{~L})$ meteorological balloon or a rebreathing bag, $\mathrm{O}_{2}$ and $\mathrm{CO}_{2}$ analyzers, a tank containing $100 \%$ oxygen, and a nose clip.

\section{Procedure}

Before initiating any contact with potential participants, the study was reviewed by the Texas Tech University Review Board for Human Subjects. Study objectives and procedures were relayed to possible study participants through an informed consent (see Appendix B).

Two-hundred and eighty-nine participants completed the Women`s Health History Questionnaire (see Appendix C) to screen for menstrual disorders and study' eligibility. This questionnaire was administered on-site at recreational or athletic facilities.

Prior to inclusion in the study, participants who answered yes to the question on the women's health history questionnaire, "Is there a possibility you could be pregnant?.". 
were asked to go to the Storks Nest, 2602 Ave. Q; Lubbock, TX 79405; (806) 762-6730. Testing consisted of providing a urine sample. There was no charge for these services. Fourteen participants met the criteria for inclusion in the study. Ten of these participants agreed to participate in the study. Body composition assessments included the following methods: (a) 7-site skinfolds measurements and Jackson's formula $[\mathrm{Db}(\mathrm{g} / \mathrm{cc}) \mathrm{b}=1.0970$ $0.00046971\left(\sum 7 \mathrm{SKF}\right)+0.00000056\left(\sum 7 \mathrm{SKF}\right)^{2}-0.00012828($ age $\left.)\right]$ to determine $\mathrm{Db}$ using Siri's equation to estimate body composition $[\% \mathrm{Fat}=(4.95 / \mathrm{Db}-4.50) \times 100]$; (b) HW to determine $\mathrm{Db}$ and Siri's equation to estimate body composition $[\%$ Fat $=(4.95 / \mathrm{Db}-$ $4.50) \times 100]$; (c) HW to determine $\mathrm{Db}$ :

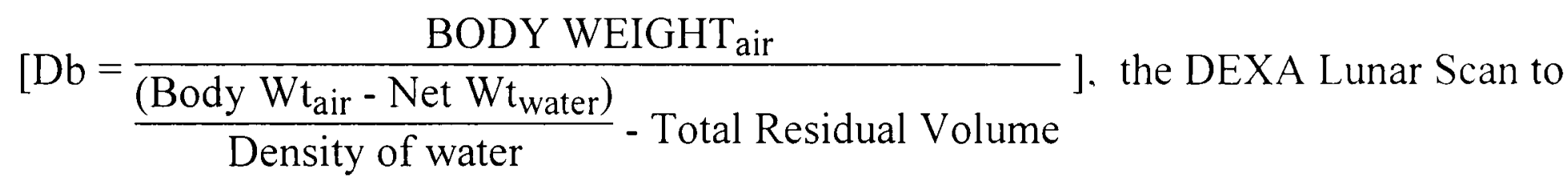

determine BMC, and Lohman's bone mineral density equation $[\%$ Fat $=(6.386 / \mathrm{Db}+$ $3.961 m-6.090) \times 100$ ] to estimate body composition; and (d) the DEXA Lunar Scan to estimate BMD and soft tissue composition.

Skinfolds assessment was obtained using standardized procedures (ACSM, 2000). The procedures are as follows: (a) all measurements were made on the right side of the body; (b) the caliper was placed $1 \mathrm{~cm}$ away from the thumb and finger. perpendicular to the skinfold, and half way between the crest and the base of the fold; (c) the pinch was maintained before and while reading the caliper; (d) measurements were taken twice and retested if measurements were not within 1 to $2 \mathrm{~mm}$; (e) measurements sites were rotated or time was allowed for skin to regain normal texture and thickness: and (f) the 2 closest values were averaged for a final skinfold thickness. Standardized description of skinfold 
sites are as follows: (a) abdominal (vertical fold); (b) triceps (vertical fold): (c) biceps (vertical fold); (d) chest (diagonal fold); (e) calf (vertical fold); (f) axillary (vertical fold); (g) subscapula (diagonal fold); (h) suprailiac (diagonal fold); and (j) thigh (vertical fold) (Jackson et al., 1980). The formula for \% BF using skinfolds can be found in Appendix D.

Standardized procedures for HW are as follows (ACSM, 2000): (a) the participant was asked to urinate prior to testing; (b) the participant wore a bathing suit; (c) the RV and dry weight were taken before hydrostatic weighing; (d) the participant sat on a chair attached to a scale suspended over a tank of water; (e) during the actual weighing procedure, the participant exhaled to RV, held their breath and sat very still while submerged on the chair; ( $f$ ) the midpoint of the range of fluctuation was recorded; and (g) the highest obtained weight was used if observed more than twice, if this criteria was not met, the second highest obtained weight was used if observed more than once. if neither the first nor the second criteria were met, the third highest weight was used if observed more than once. The procedure required multiple attempts for submersion, stabilization on scale, and determination of underwater weight (Jackson et al.. 1980). The formula for $\mathrm{Db}$ from HW can be found in Appendix D.

The procedure for the measurement of RV was as follows: (a) the rebreathing bag was flushed at least three times with $100 \%$ oxygen, then refilled with 3-5 liters of oxygen; (b) the bag was filled to approximately $80 \%$ of the total volume of the bag: (c) the participant was seated comfortably with a nose clip and mouthpiece in place: (d) the participant completed 3-5 normal breathing cycles. then exhaled to residual volume: (e) when the participant indicated attainment of RV, the stopcock was turned to the 
rebreathing bag so the participant was connected to the rebreathing bag: (f) the participant took 5-7 deep breaths at a rate of $2 \mathrm{sec}$ per breath, then exhaled to residual volume at the end of the last breath; (g) when the participant reached RV. the valve was switched so the participant was back to breathing room air; and (h) the $\mathrm{O}_{2}$ and $\mathrm{CO}_{2}$ concentrations of the rebreathing bag were measured, and RV was calculated according to Wilmore (1980). The equation used for the RV calculation from $\mathrm{O}_{2}$ dilution technique was: $\mathrm{RV}=\left(\mathrm{VO}_{2} \times \mathrm{b}\right) \div 79.8-\mathrm{b}$, where $\mathrm{VO}_{2}$ was the volume of oxygen in the rebreathing bag at the beginning of the measurement and $b$ was the percentage of nitrogen in the rebreathing bag after the measurement; calculated as $100 \%-\% \mathrm{O}_{2}-\% \mathrm{CO}_{2}$ (Wilmore. 1969; Wilmore, Vodak, Parr, Girandola, \& Billing, 1980). For a more detailed explanation of the procedures and formulas used see Appendix E.

The participant's BMD was measured by the total body dual energy $\mathrm{x}$-ray absorptiometry (DEXA) scan. Procedure for the DEXA was as follows: (a) the participant went to the radiology lab for a DEXA scan; (b) the participant donned a gown and remained very still on a scanning table for a total body DEXA scan; (c) during the scan, the participant was exposed to approximately 3.0 mrem of radiation (less than the amount of radiation received during a chest $\mathrm{x}$-ray and equivalent to being in the sun for several hours).

Body composition estimations were also determined from the DEXA Scan. The DEXA Scan has been found to be a valid method for body composition estimation (Lohman, 1984). 


\section{$\underline{\text { Statistical Procedure }}$}

A Repeated One-Way Analysis of Variance (ANOVA) was used to determine if there was a significant difference in BF composition using 4 different methods of body composition assessment: (a) 7 site-skinfolds formula [ $\mathrm{Db}(\mathrm{g} / \mathrm{cc}) \mathrm{b}=1.0970-$ $0.00046971\left(\sum 7 \mathrm{SKF}\right)+0.00000056\left(\sum 7 \mathrm{SKF}\right)^{2}-0.00012828($ age $\left.)\right]($ Jackson et al., 1980) using Siri's Equation $[\% \mathrm{BF}=(4.95 / \mathrm{Db}-4.50) \times 100] ;(b) \mathrm{HW}$ to determine $\mathrm{Db}[\mathrm{Db}=$

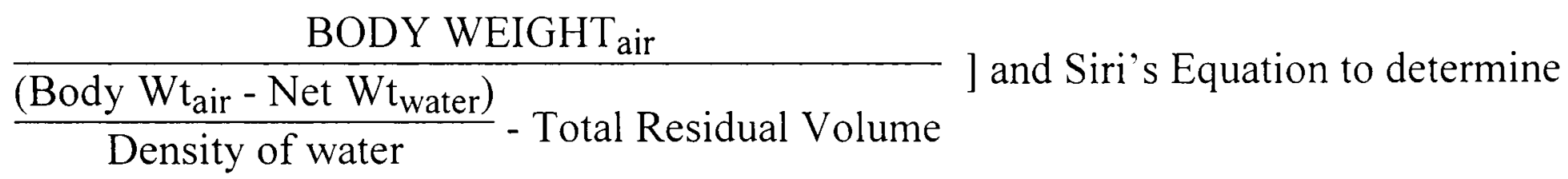
body composition $[\% \mathrm{BF}=(4.95 / \mathrm{Db}-4.50) \times 100]$ : (c) $\mathrm{HW}$ to determine $\mathrm{Db}$, the Lunar DPX IQ \#5006 DEXA scan to determine BMC and Lohman`s bone mineral density equation to determine $[\%$ Fat $=(6.386 / \mathrm{Db}+3.961 m-6.090) \times 100]$ and $(\mathrm{d})$ Lunar DPX IQ \#5006 DEXA scan to measure BMC and soft tissue composition. 


\section{CHAPTER IV \\ STATISTICS AND RESULTS}

\section{$\underline{\text { Statistical Analysis }}$}

Two hundred eighty-nine completed questionnaires were received from Texas Tech University students. Fourteen participants met the criteria for inclusion in the study. From this pool of participants, ten participants agreed to participate in this study.

Descriptive statistics for the participants are listed in Tables 4.1 to 4.5. A repeated one-way analysis of variance (ANOVA) was conducted to test for significant differences between four different methods of body composition assessment: (a) 7 site-skinfolds formula $\left[\mathrm{Db}(\mathrm{g} / \mathrm{cc})=1.0970-0.00046971\left(\sum 7 \mathrm{SKF}\right)+0.00000056\left(\sum 7 \mathrm{SKF}\right)^{2}-\right.$ 0.00012828 (age) $]$ (Jackson et al.. 1980) using Siri`s Equation $[\% \mathrm{BF}=(4.95 / \mathrm{Db}-4.50) \times$ 100]: (b) HW using the 2-component model and Siri`s Equation $[\% \mathrm{BF}=(4.95 / \mathrm{Db}-4.5())$ $\times 100]$; (c) HW using the 3-component model and Lohman`s bone mineral density equation $[\%$ Fat $=(6.386 / \mathrm{Db}+3.961 \mathrm{~m}-6.090) \times 100]$; and $(\mathrm{d})$ Lunar DPX IQ \#5006 DEXA scan to measure BMC and soft tissue composition.

Statistical significance was accepted at the $\mathrm{p}<.05$ level. The SPSS (statistical package for social science) was used for descriptive analysis and all other statistical analyses. Tables 4.1 to 4.5 detail the descriptive statistics of the study participants. 
Table 4.1 Group Descriptive Statistics of Participants

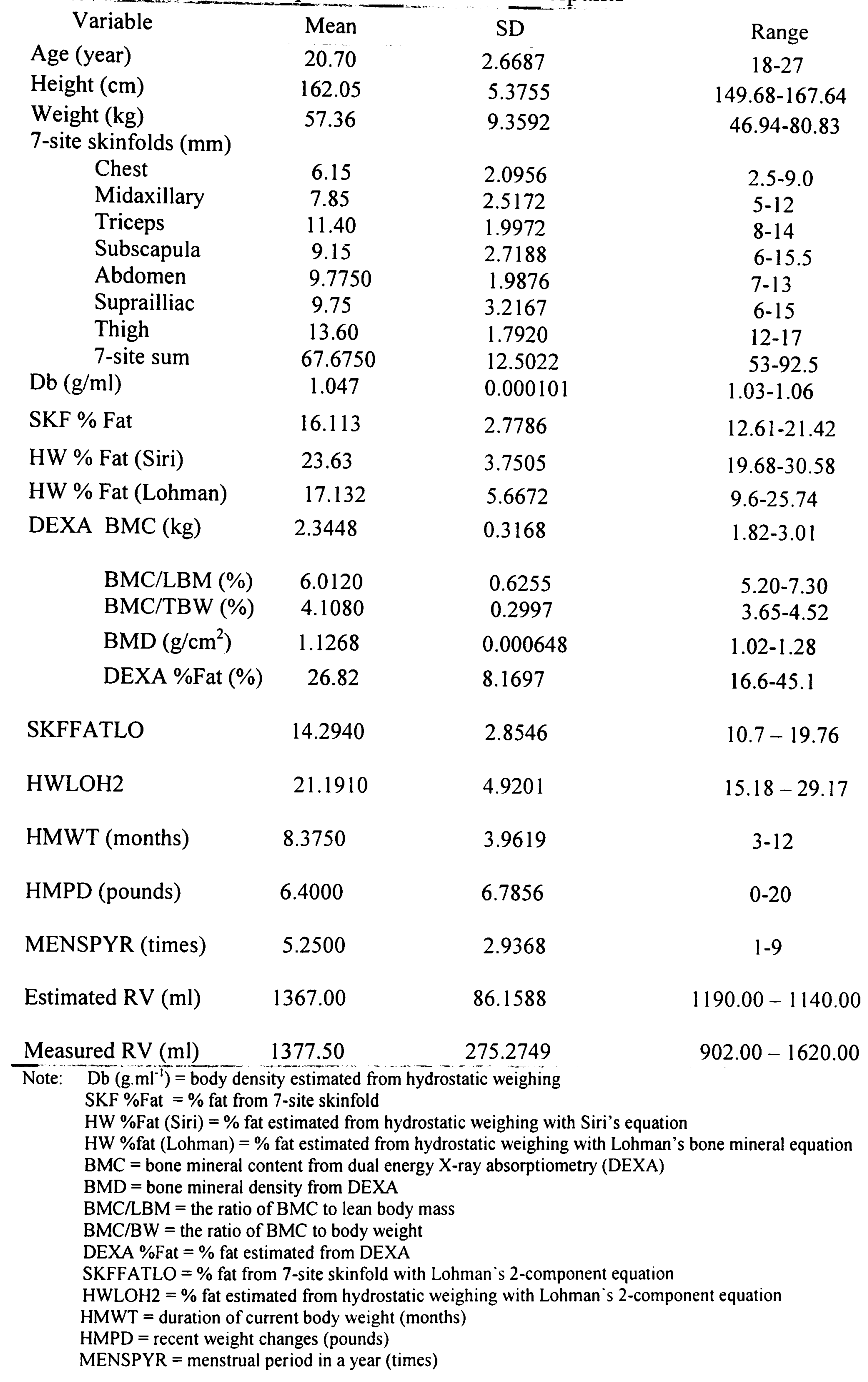


Individual group descriptive statistics of participants can be found in Tables 4.1 and 4.2. Group responses to the Women's Health History Questionnaire can be found in Tables 4.3 to 4.5 .

Table 4.2 Individual Descriptive Statistics of Participants

\begin{tabular}{|c|c|c|c|c|c|c|c|c|c|c|}
\hline Subject & 1 & 2 & 3 & 4 & 5 & 6 & 7 & 8 & 9 & 10 \\
\hline Age (year) & 20 & 20 & 21 & 23 & 18 & 19 & 18 & 21 & 20 & 27 \\
\hline Height $(\mathrm{cm})$ & $\begin{array}{l}167.6 \\
4\end{array}$ & $\begin{array}{l}167.6 \\
4\end{array}$ & $\begin{array}{l}157.4 \\
8\end{array}$ & $\begin{array}{l}149.6 \\
8\end{array}$ & $\begin{array}{l}162.5 \\
6\end{array}$ & 165.1 & $\begin{array}{l}162.5 \\
6\end{array}$ & $\begin{array}{l}160.0 \\
2\end{array}$ & 165.1 & 162.7 \\
\hline Weight (kg) & 80.83 & 58.96 & 49.89 & 46.94 & 57.6 & 54.43 & 52.84 & 62.36 & 53.52 & 56.24 \\
\hline $\mathrm{Db}\left(\mathrm{g} / \mathrm{cm}^{2}\right)$ & 1.03 & 1.06 & 1.04 & 1.05 & 1.04 & 1.04 & 1.05 & 1.04 & 1.06 & 1.06 \\
\hline Est.RV (ml) & 1440 & 1440 & 1320 & 1190 & 1440 & 1440 & 1320 & 1320 & 1320 & 1440 \\
\hline $\begin{array}{l}\text { Mea. } \\
\text { RV (ml) }\end{array}$ & 1580 & 1600 & 1550 & 1200 & 1590 & 1555 & 1056 & 1122 & 902 & 1620 \\
\hline BMC (kg) & 3.009 & 2.493 & 1.819 & 2.12 & 2.487 & 2.227 & 2.202 & 2.39 & 2.182 & 2.519 \\
\hline $\mathrm{BMC} / \mathrm{LBM}$ & 7.3 & 5.5 & 5.37 & 6.28 & 6.48 & 6.26 & 5.6 & 6.08 & 5.2 & 6.05 \\
\hline $\mathrm{BMC} / \mathrm{BW}$ & 3.72 & 4.22 & 3.65 & 4.52 & 4.32 & 4.09 & 4.17 & 3.83 & 4.08 & 4.48 \\
\hline $\operatorname{BMD}\left(\mathrm{g} / \mathrm{cm}^{2}\right)$ & 1.277 & 1.137 & 1.024 & 1.108 & 1.149 & 1.12 & 1.102 & 1.147 & 1.075 & 1.129 \\
\hline $\begin{array}{l}\text { SKF sum } \\
(\mathrm{mm})\end{array}$ & 92.5 & 69.5 & 70 & 54 & 73 & 72 & 56 & 78.25 & 53 & 58.5 \\
\hline $\begin{array}{l}\text { SKF \%fat } \\
\text { (Siri) }\end{array}$ & 21.42 & 16.98 & 16.98 & 12.61 & 16.98 & 16.98 & 12.61 & 16.98 & 12.61 & 16.98 \\
\hline $\begin{array}{l}\text { SKF\% } \\
\text { Fat } \\
\text { (Lohman) }\end{array}$ & 19.76 & 15.18 & 15.18 & 10.70 & 15.18 & 15.18 & 10.70 & 15.18 & 10.70 & 15.18 \\
\hline $\begin{array}{l}\mathrm{HW} \% \\
\text { fat (Siri) }\end{array}$ & 30.58 & 19.68 & 25.96 & 21.42 & 25.96 & 25.96 & 21.42 & 25.96 & 19.68 & 19.68 \\
\hline $\begin{array}{l}\text { HW\% } \\
\text { fat } \\
\text { (Lohman3) }\end{array}$ & 25.74 & 10.19 & 19.47 & 17.07 & 22.13 & 21.24 & 15.69 & 20.21 & 9.60 & 9.98 \\
\hline $\begin{array}{l}\text { DEXA } \\
\% \text { fat }\end{array}$ & 45.1 & 18.2 & 25.9 & 21.2 & 30.4 & 30.3 & 24.1 & 31.3 & 16.6 & 25.1 \\
\hline
\end{tabular}


Table 4.3 Physical Characteristics of Participants (see Appendix C: Women`s Health History Questionnaire)

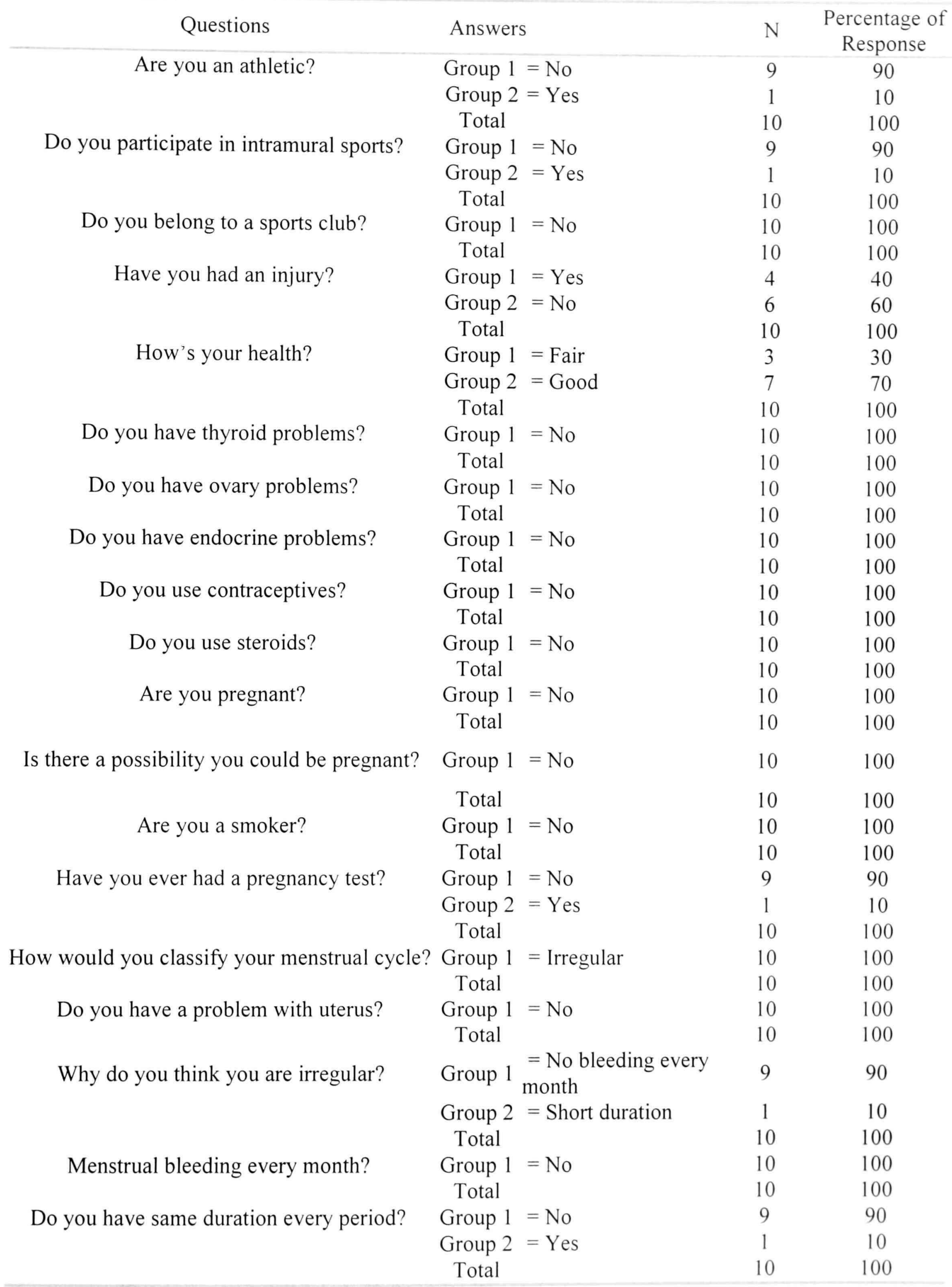


Table 4.4 Activities of Participants

\begin{tabular}{|c|c|c|c|c|}
\hline Level 1 & Frequency & Percent & $\begin{array}{c}\text { Valid } \\
\text { Percent }\end{array}$ & Cumulative Percent \\
\hline Aerobics & 5 & 50.0 & 50.0 & 50.0 \\
\hline Basketball & 1 & 10.0 & 10.0 & 60.0 \\
\hline Wt lifting & 1 & 10.0 & 10.0 & 70.0 \\
\hline Walking & 1 & 10.0 & 10.0 & 80.0 \\
\hline Racquetball & 1 & 10.0 & 10.0 & 90.0 \\
\hline Tennis & 1 & 10.0 & 10.0 & 100.0 \\
\hline Total & 10 & 100.0 & 100.0 & \\
\hline
\end{tabular}

\begin{tabular}{cccccc}
\hline Level 2 & & Frequency & Percent & Valid Percent & Cumulative Percent \\
\hline & Cycling & 3 & 30.0 & 30.0 & 30.0 \\
Jogging & 1 & 10.0 & 10.0 & 40.0 \\
Wt lifting & 1 & 10.0 & 10.0 & 50.0 \\
Tennis & 1 & 10.0 & 10.0 & 60.0 \\
None & 4 & 40.0 & 40.0 & 100.0 \\
& Total & 10 & 100.0 & 100.0 & \\
\hline
\end{tabular}

\begin{tabular}{cccccc}
\hline Level 3 & & Frequency & Percent & Valid Percent & Cumulative Percent \\
& Running & 1 & 10.0 & 10.0 & 10.0 \\
Wt lifting & 1 & 10.0 & 10.0 & 20.0 \\
Walking & 1 & 10.0 & 10.0 & 30.0 \\
None & 7 & 70.0 & 70.0 & 100.0 \\
Total & 10 & 100.0 & 100.0 & \\
\hline
\end{tabular}

\begin{tabular}{cccccc}
\hline Level 4 & & Frequency & Percent & Valid Percent & Cumulative Percent \\
& Swimming & 1 & 10.0 & 10.0 & 10.0 \\
& None & 9 & 90.0 & 90.0 & 100.0 \\
& Total & 10 & 100.0 & 100.0 & \\
\hline
\end{tabular}

\begin{tabular}{cccccc}
\hline Level 5 & & Frequency & Percent & Valid Percent & Cumulative Percent \\
& Wt lifting & 1 & 10.0 & 10.0 & 10.0 \\
None & 9 & 90.0 & 90.0 & 100.0 \\
& Total & 10 & 100.0 & 100.0 & \\
\hline
\end{tabular}

Note: The number of activities each participant engaged in was a level, ranging from 1 to 5. Participants who only participated in 1 activity are listed in level 1 , included who participated in five activities are listed in level 5. 
Table 4.5 Participants' Health History

\begin{tabular}{ccccc}
\hline Type of Injury & Frequency & Percent & Valid Percent & Cumulative Percent \\
\hline Tendon and ligament & 2 & 20.0 & 20.0 & 20.0 \\
Spinal meniscus & 1 & 10.0 & 10.0 & 30.0 \\
Muscle & 1 & 10.0 & 10.0 & 40.0 \\
None & 6 & 60.0 & 60.0 & 100.0 \\
Total & 10 & 100.0 & 100.0 & \\
\hline
\end{tabular}

\begin{tabular}{ccccc}
\hline Eating Disorders & Frequency & Percent & Valid Percent & Cumulative Percent \\
\hline Anorexia Nervosa & 2 & 20.0 & 20.0 & 20.0 \\
Bulimia Nervosa & 0 & 0 & 0 & 0 \\
None & 8 & 80.0 & 80.0 & 100.0 \\
Total & 10 & 100.0 & 100.0 & \\
\hline
\end{tabular}

$\begin{array}{ccccc} & & \text { ACTTIME } & \text { ACTHOUR } & \text { ACTSCHE } \\ \mathrm{N} & \text { Valid } & 10 & 10 & 10 \\ \text { Missing } & 0 & 0 & 0 \\ \text { Mean } \pm \text { SD } & & 7.10 \pm 5.3635 & 7.50 \pm 9.0952 & 14.70 \pm 22.6816 \\ \text { Note: } & \text { ACTTIME }=\text { activity times in a week (times) } & & \\ \text { ACTHOUR = activity hours in a week (hours) } & & \\ \text { ACTSCHE }=\text { duration of activity schedules (months) } & \end{array}$

A repeated one-way ANOVA was conducted to test for significant differences among four different methods of body composition analysis. Results are listed in Appendix I. There was a significant difference among the four methods incorporating both 2-component and 3-component models, $F(3,27)=26.89 . p<.05$.

Follow up tests among the four different body composition methods included paired sample t-test between all the possible combinations (see Appendix $\mathrm{J}$ ). Paired $\mathrm{t}$ tests demonstrated a significant difference between the following measurement techniques: (a) skinfold \% fat using Siri’s equation and hydrostatic weighing ${ }^{\circ} 0$ fat using Siri`s equation (SKFFATSI - HWFATSI), $\mathrm{t}(9)=-9.115, \mathrm{p}<.05$; (b) skinfold \% fat using Siri's equation and DEXA \% fat (SKFFATSI - DFXAFAT), t $(9)=-5.46+\mathrm{p}<.(1) 5$. (c) 
hydrostatic weighing \% fat using Siri's equation and hydrostatic weighing $\%$ fat using Lohman's bone mineral density equation (HWFATSI - HWFATLOH3). $t(9)=8.6+7 . p$ $<.05$; and (d) hydrostatic weighing \% fat using Lohman`s bone mineral density equation and DEXA \% fat (HWFATLOH3 - DEXAFAT), $t(9)=-6.839, \mathrm{p}<.05$.

In an effort to further understand the data, correlation coefficients were run between $\mathrm{Db}, \mathrm{BMD}, \mathrm{BMC}$, and the 2- and 3-component models (see Appendix $\mathrm{K}$ ). Additionally, Lohman's equation for BF composition (Lohman. 1981) $[\%$ fat $=(5.09 / \mathrm{Db}$ $-4.65) \times 100$ ] was used to calculate the percentage of BF from skinfold measurements using $\mathrm{Db}$ in the equation as calculated from Jackson's equation (Jackson et al.. 1980) and also using Db from HW utilizing the 2-component model as with Siri’s equation. This increased the number of levels from four to six in the repeated measurement analysis (see Appendix L and M). There was a significant difference among levels, $F(5,45)=29.16, p$ $<.05$. Only significant comparisons between the two additional levels (Lohman`s 2component equation for SKF and HW) will be discussed, since the previous four level comparisons are the same: (a) skinfold $\%$ fat using Siri`s equation and skinfold $\%$ fat using Lohman's 2-component equation (SKFFATSI - SKFFATLO). $t(9)=75.465, \mathrm{p}$ $<.05$; (b) hydrostatic weighing $\%$ fat using Siri's equation and hydrostatic weighing $\%$ fat using Lohman`s bone mineral density equation (HWFATSI - HWFATLOH3). $\mathrm{t}(9)=$ $8.647, \mathrm{p}<.05$; (c) hydrostatic weighing $\%$ fat using Siri`s equation and hydrostatic

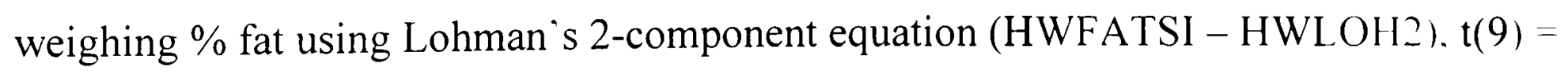
5.417, $\mathrm{p}<.05$; (d) hydrostatic weighing \% fat using Lohman`s bone mineral density equation and hydrostatic weighing \% fat using Lohman`s 2-component c'puation 
(HWFATLOH3 - HWLOH2), $\mathrm{t}(9)=-11.370, \mathrm{p}<.05 ;$ (e) DEXA $\%$ fat and skinfold $\%$ fat using Lohman's 2-component equation (DEXAFAT - SKFFATLO), $t(9)=3.903 . p$ $<.05$; and (f) skinfold \% fat using Lohman's 2-component equation and hydrostatic weighing \% fat using Lohman's 2-component equation (SKFFATLO - HWLOH2). t(9) $=-5.558, \mathrm{p}<.05$. 


\section{CHAPTER V}

\section{DISCUSSION AND CONCLUSIONS}

\section{$\underline{\text { Discussion }}$}

\section{General Introduction}

The women's skinfold thickness and corresponding \% BF using Siri's equation in this group of participants was significantly lower than that of normal women. According to Jackson et al. (1980), the sum of SKF for normal women was $110.40 \pm 34.10(\mathrm{~mm})$ and SKF \% fat was $21.80 \pm 6.40$ using Siri's equation. According to Lohman (1981), the SKF \% fat for the reference woman was $26.90 \%$ using Siri’s equation. Baker et al. (1988) found that oligomenorrheic women \% fat was $15.61 \pm 1.21 \%$ using SKF with Siri`s equation. In this group of participants, the sum of SKF was $67.68 \pm 12.50(\mathrm{~mm})$ and SKF \% fat was $16.11 \pm 2.78$ using Siri's equation.

Other studies found that percent BF using the 2-component model using HW with Brozek's equation for oligo/amenorrheic female athletes was $17.40 \pm 1.10 \%$ and for eumenorrheic athletes' was $24.70 \pm 1.59 \%$ (Howat et al., 1989). In this study. the 2component model using HW was $23.63 \pm 3.75$.

Since there was a high correlation $(r=.703)$ between measured RV and estimated $\mathrm{RV}$ in this study $(\mathrm{p}<.05)$, one would not expect that $\mathrm{Db}$ would be affected by estimating $\mathrm{RV}$. There does not seem to be a difference in $\mathrm{Db}$ between normal values and the values of the participants in the study. Db was $1.04 \pm 0.01\left(\mathrm{~g} / \mathrm{cm}^{2}\right)$ in this study. Reference Db 
values for females have been estimated to be $1.05 \pm 0.01\left(\mathrm{~g} / \mathrm{cm}^{2}\right)$ (Jackson et al.. 1984) and $1.04 \pm 0.01\left(\mathrm{~g} / \mathrm{cm}^{2}\right)$ (Linnell et al., 1984).

Normal content of BMD has been reported as $1.37 \pm 0.04 \mathrm{mg} / \mathrm{cm}^{2}$ (Howat et al.. 1989). Howat et al. (1989) found that oligo/amenorrheic women's mean bone density was $1.17 \pm 0.03 \mathrm{mg} / \mathrm{cm}^{2}$. Cann et al. (1984) also found that spinal bone mass was decreased in all amenorrheic women $22 \%$ to $29 \%$ from normal values. BMD was $1.13 \pm 0.000648$ $\left(\mathrm{g} / \mathrm{cm}^{2}\right)$ in this study.

Total BMC of the participants in this study was below that expected for this age group (age 18-27). In the present study, total BMC was $2.34 \pm 0.31(\mathrm{~kg})$. According to Hansen et al. (1993). normal values for total BMC has been reported as $2.56 \pm 0.46$ ( $\mathrm{kg}$ ) for women age 28 to 39 yrs. However. few researchers have used total BMC in their study but rather BMC has been estimated based on the content of regional sites (radius. hip and lumbar vertebrae).

The ratio of $\mathrm{BMC} / \mathrm{LBM}$ for the reference person is $6.8 \pm 0.9 \%$. In the present study, BMC/LBM was $6.01 \pm 0.63 \%$. Furthermore, the ratio of BMC to total body " weight (BW) was even lower, $4.11 \pm 2.99 \%$. Linnell et al. (1984) found that the BMC/BW (estimated from the radius) for the five leanest amenorrheic runners in their study was $7.40 \pm 3.60 \%$ and for the five fattest runners was $17.10 \pm 3.70 \%$. 


\section{$\underline{\text { Specific Findings }}$}

The purpose of this research project was to determine if the BMC of oligomenorrheic women significantly alters body composition estimations. More specifically, the question was will there be a different body composition estimation when BMC is included in the model for this specific population. Because of the inconsistency in findings within and between the 2-component models and the 3-component models in this study, it seems that body composition estimations depend more on the method or equation chosen for that population rather than the number of components included in the model. In the present study, the 2-component equation resulted in body composition estimations ranging from $16.11 \pm 2.78 \%$ to $23.63 \pm 3.75 \%$. Three-component models yielded results ranging from $17.13 \pm 5.67 \%$ to $26.82 \pm 8.17 \%$. Since there was not an agreement between the 3-component models which include BMC nor the 2-component models which do not include BMC, but surprisingly, agreement between the 2 and 3 component models, the question must be raised, "Which body composition estimation method is most accurate and how reliable are the different body composition measurements?"

To answer this question, one must look at the standard error of estimates of the methods. DEXA has been shown to have a standard error of $\sim 2 \%$, considerably less than traditional methods (Wellens et al., 1993). The advantage of using DEXA to study body composition is that a direct determination of $\mathrm{BMC}, \mathrm{BMD}$, and $\% \mathrm{BF}$ of the entire bod! can be obtained. Clark et al. (1993) reported that the difference in \% fat betwcen the methods was dependent upon the percentage of bone and suggests an inadequate 
correlation for variation in bone mass in the HW technique may explain $50-66 \%$ of the difference in $\%$ fat between DEXA and HW.

Even though DEXA has been considered to be an exact measurement for body composition, the results in this study from DEXA are questionable. In this study, the mean DEXA \% fat was $26.82 \pm 8.17 \%$. Four participants' DEXA $\%$ fat were over $30 \%$ and one participant had a body composition estimation of $45 \%$. The large difference in individual data between DEXA and the other 3 methods. and the fact that obesity is considered to be a BF content above $30 \%$ for young women aged 17 to 27 yrs, suggests that we should interpret the results from DEXA with caution. A Body Mass Index (BMI) is used to access weight relative to height and is calculated by body weight $(\mathrm{kg}) /$ height $\left(\mathrm{m}_{2}\right)$. A BMI value $>30$ is considered to constitute obesity (ACSM, 2000). None of the participants in this study had a BMI of 30 or greater. However. we still do not know for sure whether these results are valid given the past research findings which states the validity and accuracy of DEXA measurements (Clark et al.. 1993).

Measurements of human body composition by indirect techniques such as HW and SKF have larger errors than direct methods (Going et al., 1990). The standard error for SKF is estimated to be $\sim 5 \% \mathrm{BF}$; depending on the prediction equation and the sample of subjects, some reported errors have ranged from 3 to $9 \%$ BF (Lukaski. 1987). HW may have a $2 \%-4 \%$ error, depending on the population (Lohman, 1982). According to Katch (1980), when HW is used to measure $\mathrm{Db}$, the variance is $\pm 3.8 \%$. This crror may come from the variance in FFB component. HW may also have inconsistencies because of the participant's movement in water. and variation in equipment and methodologies all 
contribute to errors in $\mathrm{HW}$. When evaluating estimations of $\% \mathrm{BF}$ using the 2-component model, it should be recognized that part of the error may be associated with BMC and its influence on $\% \mathrm{BF}$.

The difference between of $\%$ BF was $6.4 \%$ when using Db from HW' and comparing Siri’s 2-component and Lohman`s 3-component equations in this study. To be within the $95 \%$ confidence interval for a given population. Lohman (1992) stated that if the estimation of mineral (BMC/lean body mass) was $6.80 \pm 0.90 \%(5.9-7.7 \%)$ in a given population, one could expect that the results obtained from Siri's 2-component equation and from Lohman's 3-component equation would be similar. In this study. BMC as a fraction of lean body mass (LBM) was $6.01 \pm 0.62 \%(5.2-7.3 \%)$. This range was below that required for the $95 \%$ confidence interval. It is understandable that different results would be obtained based on this reference. The 2-component model (fat and fat free body component) assumes that the composition and density of the FFB component are constant among individuals. According to the results of a study by Going et al. (1990). this assumption may not be valid for all groups and significant errors in estimating body composition could result if the assumptions are not valid.

Even though there are errors in estimations when using HW. HW has served as the gold standard to determine the validity of body composition methods (Lukaski et al., 1987). According to the results of this study, there was a high correlation between HWFATSI and HWFATLOH3 $(r=.954)$. HWFATSI and DEXAFAT were also highly correlated $(\mathrm{r}=.912)$. The high correlation between DEXA and HW suggests that DIXXI 
may be a viable method for predicting $\% \mathrm{BF}$. Therefore, it seems that both $\mathrm{HW}^{\mathrm{a}}$ and DEXA are accurate measurements for estimating $\% \mathrm{BF}$.

\section{$\underline{\text { Conclusions }}$}

In most clinical situations, measurements of body composition are limited to only one method (Katch, 1980). The method chosen depends on the validity and reliability of the method as well as the practicality of using that method (Hassager et al., 1994). The purpose of this study was to determine if this specific population would have different body composition assessment results when BMC was used in the equation. Because of the inconsistency in the findings among the estimations using either the 2-component or 3-component model, we cannot answer that question. There was no difference in the 2component model when using Jackson's 7-site skinfold formula to estimate Db and Siri`s equation and Lohman's 3-component model. Additionally there was a significant difference between the 3-component models in percentage of BF when comparing the DEXA results and Lohman`s bone mineral density equation. Based on the results of this study, it seems that the method and equation chosen has the greatest impact on body composition estimations rather than the number of components included in the model.

A number of factors should be considered when selecting one or more methods for assessing body composition for a specific population. Some factors to consider are time, money, ethnicity, and gender (Wellens et al., 1993). Perhaps more than one method should be used to compare the results obtained for that population. Lohman (1984) stated that research has been marked by an emphasis in using only one method to estimate bod! 
composition, and this has led to inaccurate body composition estimations. The difficult question becomes which method is the most valid. We cannot answer that question based on the conflicting results obtain within and between 2- and 3-component models.

\section{$\underline{\text { Suggestions for Further Research }}$}

The suggestions which follow may be helpful to continue the research begun in the present study.

1. Inconsistencies between DEXA and hydrostatic weighing in the prediction of $\% 0$ fat should be identified in future research.

2. Comparison of the 2- and the 3-component models for the purpose of understanding the contribution of an added variable in the equation should be limited to only one method.

3. Future research should utilize a control group to see if the differences found between the 2-component and 3-component models is the same for both eumenorrheic and oligomenorrheic women. 


\section{BIBLIOGRAPHY}

Adami, S. ,Zamberlin, N. ,Castello, R. .Tosit. F.. Gattl. D..\& Moghetti, P. (1998). Effect on hyperandrogenism and menstrual cycle abnormalities on bone mass and bone turnover in young women. Clinical Endocrinology, 48, 169-173.

American Collage of Sports Medicine (2000). ACSM's guidelines for exercise testing and prescription. $\left(6^{\text {th }}\right.$ ed.). Baltimore, MD: Wolters Kluwer Company.

Bachmann, G., A., \& Kemmann, E. (1982). Prevalence of oligomenorrhea and amenorrhea in a college population. American Journal of Obstetrics and Gynecology, 144(98), 98-102.

Baker, E., \& Demers, L. (1988). Menstrual status in female athletes: Correlation with reproductive hormones and bone mineral density. American Journal of Obstetrics and Gynecology, 72(5), 683-687.

Barrow; G. W.. \& Saha, S. (1988). Menstrual irregularity and stress fractures in collegiate distance runners. The American Journal of Sports Medicine, 16(3). 209-216.

Bemben, D. A. (1999). Exercise interventions for osteoporosis prevention in postmenopausal women. The Journal of Oklahoma State Medical Association, 92(2).

Bemben, D. A.. \& Fetters, N. L. (2000). The independent and addictive effects of exercise training and estrogen on bone metabolism. Journal of Strength and Conditioning Research, 14(1), 114-120.

Bullen, B. A. . Skrinar. G. S. . Beitins. I. Z. , Mering, G. , Turnbull, B. A. . \& McArthur. J. W. (1985). Introduction of menstrual disorders by strenuous exercise in untrained women. The New England Journal of Medicine, 312. 1349-1353.

Bunt, J. C., Going, S. B.. Lohman. T. G.. Heinrich, C. H.. Perry, C. D., \& Pamenter, R. II (1989). Variation in bone mineral content and estimated body fat in young adult females. Medicine and Science in Sports and Exercise, 22(5), 564-569.

Calabrese, L. H.. Kirkendall. D. T.. Floyd, M.. Rapoport, S., Williams. G. W'. Wciker, G. G. (1983). Menstrual abnormalities, nutrition, and body composition in female dancers. The Physician and Sports Medicine, 11(2). 86-98.

Cann, C. E.. Martin, M. C.. Genant, H. K.. \& Jaffe, R. B. (1984). Decreased spinal mineral content in amenorrheic women. JAM.A. 251(5). 626-629. 
Carlberg, K. A.. Buckman, M. T., Peake, G. T.. \& Riedesel, M. L. (1983). Body composition of oligo/amenorrheic athletes. Medicine and Science in Sports and Exercise, 15(3). 215-217.

Cavanaugh, D. J., Kanonchoff, A. D.. \& Bartels, R. L. (1989). Menstrual irregularities in athletic women maybe predictable based on pre-training menses. The Journal of Sports Medicine and Physical Fitness, 29(2), 163-169.

Clarck. R.. Kuta, J.. \& Sulivan, J. (1993). Prediction of percent body fat in adult males using dual energy x-ray absorptiometry. skinfolds, and hydrostatic weighing. Medicine and Science in Sports and Exercise. 25(4). 528-535.

Clarkson, P. M.. \& Haymes, E. M. (1995). Exercise and mineral status of athletes: Calcium, magnesium, phosphorous. and iron. Medicine and Science in Sports and Exercise, 27(6), 831-843.

Dale, E., Gerlach. D., \& Wilhite, A. L. (1979). Menstrual dysfunction in distance runners. Obstetrics and Gynecology, 54(1), 47-53.

Dalsky, G. P. (1990). Effect of exercise on bone: permissive influence of estrogen and calcium. Medicine and Science in Sports and Exercise. 22(3), 281-285.

Davee, M. A., Rosen, J. C., \& Alder, A. R. (1990). Exercise patterns and trabecular bone density in college woman. Journal of Bone and Mineral Research, 5(3), 245-250.

Drinkwater, B. L., Nilson, K.. Chesnut III. C. H.. Bremner. W. J., Shainholtz, S.. \& Southworth, M. B. (1984). Bone mineral content of amenorrheic and eumenorrheic athletes. The New England Journal of Medicine. 311(5). 277-280.

Drinkwater, B. L.. Bruemner, B., \& Chesnut, C. H. (1990). Menstrual history as a determinant of current bone density in young athletes. JAMA. 263 (4). 545-548.

Fahey, T. D.. Insel. P. M.. \& Roth, W. T. (1999). Fit \& Well. ( $3^{\text {rd }}$ ed.). Mountain View. CA: Mayfield Publishing Company.

Frisch, R. E., Gotz-Welbergen, A. V., McArthur. J. W.. Albright, T.. Witschi, J.. Bullen. B., Birnholz, J., Reed, R. B.. \& Hermann, H. (1981). Delayed menarche and amenorrhea of college athletes in relation to age of onset of training. JAMA. 246(14), 1559-1563.

Frost, H. M. (1990). Skeletal structural adaptations to mechanical usage: 1. Redefinin Wolff's law: The bone remodeling problem. Anatomical Record. $226(4) .4(13-413$ 
Frost, H. M. (1999). On the estrogen-bone relationship and postmenopausal bone loss: A new model. Journal of Bone and Mineral Research, 14(9), 1473-1477.

Hansen, N. J., Lohman, T. G., Going, S. B., Hall. M. C., Pamenter. R. W.. Bare. L. A. (1993). Prediction of body composition in premenopausal females from dual-energy X-ray absorptiometry. Journal of Applied Physiology, 75(4). 1637-16+1.

Harber, V. J. (1999). Menstrual dysfunction in athletes: An energetic challenge. Exercise and Sports Science Reviews, 28(1), 19-23.

Hassager. C., \& Christiansen, C. (1994). Measurement of bone mineral density. Calcified Tissue International, 57, 1-5.

Heinrich, C. H., Going, S. B., Pamenter, R. W., Perry. C. D., Boyden, T. W.. \& Lohman. T. G. (1990). Bone mineral content of cycling menstruating female resistance and trained athletes. Medicine and Science in Sports and Exercise, 22 (5). 558-563.

Howat, P. M., Carbo, M. L., Mills, G. Q.. \& Wozniak. P. (1989). The influence of diet. body fat, menstrual cycling, and activity upon the bone density of females. Journal of The American Dietetic Association, 89(9), 1305-1307.

Jackson, A. S.. Pollock. M. L., \& Ward, A. (1980). Generalized equations for predicting body density of women. Medicine and Science in Sports and Exercise, 12(3), 175182.

Jebb, S. A., Goldberg, G. R., \& Elia, M. (1993). DXA measurements of fat and bone mineral density in relation to depth and adiposity. Basic Life Science, 60, 115-120.

Jurimae, T., Jagomagi. G.. \& Lepp, T. (1992). Body composition of university students by hydrostatic weighing and skinfold measurement. Journal of Sports Medicine and Physical Fitness, 32(4), 387-393.

Kaplan, G. (1985). Prevention and management of osteoporosis. Clinical Symposia, $\underline{47}(1), 2-32$.

Linnell, S. L.. Stager. J. M.. Blue. P. W.. Oy ster. N.. \& Robertshaw. D. (1984). Bone mineral content and menstrual regularity in female runners. Medicine and Science in Sports and Exercise. 16(4). 343-348.

Lloyd, T., Triantafyllou, S. J.. Baker. E. R.. Houts. P. S.. Whiteside, J. A.. Kalenak. A.. \& Stumpf, P. G. (1986). Women athletes with menstrual irregularity have increased musculoskeletal injuries. Medicine and Science in Sports and Excrcise. 18 $(4) .374$ 379. 
Lloyd, T.. Buchanan, J.. Bitzer, B., Waldman, C.. Myers. C., \& Ford. B. (1987). Interrelationship of diet, athletic activity. menstrual status, and bone density in collegiate women. American Journal of Clinical Nutrition, +6, 681-684.

Lohman, T. G. (1981). Skinfolds and body density and their relation to body fatness: A review. Human Biology, 53, 181-225.

Lohman, T. G. (1982). Body composition methodology in sports medicine. The Physician and Sports Medicine, 10(12), 47-58.

Lohman, T. G. (1984). Research progress in validation of laboratory methods of assessing body composition. Medicine and Science in Sports and Exercise, 16 (6). 596-603.

Lohman, T. G. (1992). Advances in body composition assessment. Champaign, IL: Human Kinetics.

Loucks, A. B., \& Horvath, S. M. (1985). Athletic amenorrhea: A review. Medicine and Science in Sports and Exercise, 17(1), 56-72.

Loucks, A. B. (1990). Effects of exercise training on the menstrual cycle: existence and mechanisms. Medicine and Science in Sports and Exercise, 22(3), 275-279.

Lukaski, H. C. (1987). Methods for the assessment of human body composition. American Journal of Clinical Nutrition, 46, 537-556.

Lutter, J. J. \& Cushman, S. (1982). Menstrual patterns in female runners. The Physician and Sports Medicine, 10, 60-72.

Marcus. R., Cann, C., Madvig, P., Minkoff, J., Goddard, M.. Bayer. M., Martin, M.. Gaudiani, L.. Haskell, W., \& Genant, H. (1985). Menstrual function and bone mass in elite woman distance runners. Annals of Internal Medicine, 102. 158-163.

Maud, P. J \& Foster. C. (1995). Physiological assessment of human fitness. Champaign. IL: Human Kinetics.

Mazess. R., Barden, H.. Bisek, J., \& Hanson, J. (1990). Dual-energy x-ray absorptiometry for total-body and regional bone-mineral and soft tissue composition. American Journal of Clinical Nutrition, 51(6), 1106-1112.

Nattive. A., Agostini, R., Drinkwater, B.. \& Yeager. K. K. (1994). The female athlete triad: The inter-relatedness of disordered eating, amenorrheia. and osteoporosis. Clinics in Sports Medicine, 13(2), 405-418. 
Nelson, M. B., Fisher, E. C., Catos, P. D., Meredith, C. N., Turksoy, R. N.. \& Evans. W'. J. (1986). Diet and bone status in amenorrheic runners. American Journal of Clinical Nutrition, 43, 910-916.

Oppliner, R., Lonney, M., \& Tipton, C. (1987). Rehabilitation of hydrostatic weighing \& skinfold measurements of body composition using generalized study. Biology, 59, 77-96.

Parazzini, F., Bidoli, E., Franceschi, S., Schinella, D., Tesio, F., LaVecchia. C., \& Zecchin, R. (1996). Menopause, menstrual and reproductive history. and bone density in northern Italy. Journal of Epidemiology and Community Health. 50, 519 523.

Perrone, G., Galoppi, P., Capri, O., Anelli, G., Borrello, M., \& Zichella, L. (1995). Lumbar and femoral bone density in premenopausal women irregular cycles. International Journal of Fertility and Menopausal Studies. 40(3), 120-125.

Ramos, R. H., \& Warren, M. P. (1995). The interrelationships of body fat, exercise. and hormonal status and their impact on reproduction and bone health. Seminars in Perinatology, 19(3), 163-170.

Reid, I., Ames, R., Evans, M., Sharpe, S.. \& Gamble, G., France, J. T.. Lim. T. M. T., \& Gundy, T. F. (1993). Determinants of total body and regional bone mineral density in normal postmenopausal women - A key role for fat mass. American Journal of Obstetrical \& Gynecological Survey, 48(1), 61-63.

Rodan, G. A. (1992). Introduction to bone biology. Bone, 13, S3-S6.

Salamon, L. M., Gregg, E., Wolf, R. L.. Epstein, R. S., Black, D., Palermo, L., Kuller, L. H., \& Cauley, J. A. (1998). Are menopausal symptoms associated with bone mineral density and changes in bone mineral density in premenopausal women? Journal of the Climacteric \& Postmenopause, 29, 179-187.

Scott, J., Disaia, P., Hammond, C., \& Spellacy. W. (1984). Danforth's obstetrics and gynecology. Philadelphia, PA: J.B. Lippincott Company.

Singh, K. B. (1981). Menstrual disorders in college students. American Journal of Obstetrics \& Gynecology, 140(3), 299-302.

Snow-Harter, C.. \& Marcus, M. (1991). Exercise, bone mineral density. and osteoporosis. Exercise and Sport Science Reviews, 19(10). 351-388.

Speroff, L., \& Redwine, D. B. (1980). Exercise and menstrual function. The Phy sician and Sports Medicine, 8, 42-48. 
Thomas, J. R.. \& Nelson, J. K. (1996). Research methods in physical activity. ( $3^{\text {rd }}$ ed.). Champaign, IL: Human Kinetics.

Verlooy, H., Dequeker. J. Geusens. P.. Nijs. J.. \& Goris. M. (1991). Body composition by intercomparison of hydrostatic weighing, skinfold measurements, and dual-photon absorptiometry. The British Journal of Radiology, 64, 765-767.

Wellens, R., Roche, A. F., Guo, S., Chumlea, W. C., \& Siervogel, R. M. (1993). Fat-free mass and percent body fat assessments by dual-energy $\mathrm{x}$-ray absorptiometry and total body water. Basic Life Sciences, 60, 71-74.

Wilmore, J. H. (1969). A simplified method for determination of residual lung volumes. Journal of Applied Physiology, 27(1), 96-100.

Wilmore, J. H, Vodak, P. A., Parr, R. B., Girandola, R. N., \& Billing, J. E. (1980). Further simplification of a method for determination of residual lung volume. Medicine and Science in Sports and Exercise, 12(3), 216-218. 


\section{APPENDIX A}

\section{SCRIPT TO BE USED TO RECRUIT VOLUNTEERS FOR THIS STUDY}




\section{Script To Be Used To Recruit Volunteers For This Study}

Hello. my name is Namju Lee. I am a graduate student in the Department of Health, Physical Education and Recreation (HPER). Dr. Jacalyn M/cComb and I are conducting a study for which we are seeking volunteers. We need 12 volunteers in this study. The purpose of this research project is twofold: (a) first we must determine if women with abnormal menstrual cycles have decreased bone mineral content: (b) secondly, we want to see if this has an effect on body composition estimations. Decreased bone mineral content in women with abnormal menstrual cycles could cause mistakes in estimating body fat.

After signing the consent form, you will go through two stages of screening in order to qualify for participation in the study. The first stage is for you to complete a Women's Health Questionnaire. In order to be a participant in the study you must be (a) female: (b) 18-25 years of age; (c) exercising at least 45 minutes a day for + times a week: (d) have irregular menstrual cycles for at least 6 months; (d) not have a history of oral contraceptive and hormone use: (e) not be pregnant, and (f) a nonsmoker. In stage 2 . you will be asked to have a pregnancy test if you are unsure about the possibility of pregnancy. If there is a possibility that you might be pregnant, you will be asked to go to the Storks Nest. 2602 Ave. Q: Lubbock, TX 79405; (806) 762-6730. The Storks Nest is open Monday through Friday from 8:30 - 5:30. it is closed from 12:00-1:00 for lunch. Testing consists of a urine sample. It is a community service program operated by University Medical Center. There is no charge for their services.

Provided that you meet the criteria for inclusion in the study, your body fat will be assessed by two methods: 1) the 7- site skinfolds measurement and 2) hydrostatic weighing. You will schedule an appointment with the investigator to measure your body composition. Body composition will be assessed at the Men's Gym at Texas Tech University, Room 117. Total body DEXA scan will be performed to measure the mineral in your bone. The bone scan will be conducted at Dimensions Center for Women's Health. UMC. 602 Indiana Avenue: Lubbock, TX 79415: (806) 7+3-4377. Your participation in the study will cost you your time and energy. We anticipate the time cost to be 3 hours. given the time required for body component assessment and bone mineral measurements. Completion of the Women`s Health Questionnaire may be stressful for some women if they recognize potential existing health problems, which require treatment. Hydrostatic weighing may cause some discomfort to participants who are afraid of water.

The benefits to you from your participation in the study are the following. This study will benefit the participants involved by providing information about their bone mineral content and body fat levels at no cost to the participant. The cost of bone mineral density assessment using DEXA ranges from $\$ 180.00$ to $\$ 235.00$. The cost of hydrostatic weighing is $\$ 50.00$. This study will benefit other individuals by providing information that can be used to more accurately determine the body' fat levels of active women with menstrual disorders. This study will also benefit the participants involved by providing information about their current bone mineral content and body fat levels at no cost to the participant. This information has a market value of $\$ 285.00$. Thank you for your attention. I will now respond to your questions. and accept volunteers for the study. 
APPENDIX B

CONSENT FORM 


\section{Consent Form}

I hereby give my consent for my participation in the project entitled: Does the Mineral Bone Content of Oligomenorrheic Active Women Have an Affect on Body Composition Estimations?

I understand that the investigators responsible for this project are Dr. Jaclyn McComb. (806) 742-3371, and Namju Lee (806) 780-3114.

\section{Explanation of the Purpose and Procedures}

The investigators have explained to me that the purpose of this study is to measure the bone mineral content of active women who have abnormal menstrual cycles and to see if the amount of their bone mineral content has an affect on body composition estimations. Decreased bone mineral content in women could cause mistakes in estimating body fat.

The investigators or their authorized representatives have explained the procedures as follows: My participation will involve a total of approximately $3-t$ hours. This will consist of answering a Women's Health Questionnaire. If there is a possibility that I may be pregnant, I will be asked to go the Storks Nest, 2206 Ave. Q to have a urine sample taken. Following the screening procedures. I will have body composition and bone mineral assessed. The actual testing time following screening is as follows: (a) a 7site skin fold assessment (approximately $30 \mathrm{~min}$ ); (b) hydrostatic weighing (approximately $30 \mathrm{~min}$ ); and (c) total body DEXA scan (approximately $30 \mathrm{~min}$ ).

The body composition procedure involves assessment of subcutaneous fat at seven sites using a skinfold caliper. You will be asked to wear a bathing suit. Hydrostatic weighing will be performed after the skinfold measurement. While still in the bathing suit. you will be asked to sit on a seat attached to a scale that is suspended over a tank of water. During the actual weighing procedure. you will be asked to exhale as much air as possible, hold the breath and sit very still while submerged on the seat. You may voluntarily rise out of the water as necessary to breathe and/or maximize your comfort with the procedure. This procedure may require multiple attempts for submersion, stabilization of the scale, and determination of underwater weight.

You will be asked to go to the radiology lab for a DEXA scan. You will be asked to don a gown and to lie very still on a scanning table for a total body DEXA scan. During the scan, you will be exposed to approximately $10 \%$ of the radiation that you receive during a chest $\mathrm{x}$-ray or an $\mathrm{x}$-ray of a broken bone. This is equivalent to being in the sun for several hours.

\section{Benefits}

The benefits to you from your participation in the study are the following. This study will benefit the participants involved by providing information about their bone mineral content and body fat levels at no cost to the participant. The cost of bone mineral density assessment using DEXA ranges from $\$ 180.00$ to $\$ 235.00$. The cost of hydrostatic weighing is $\$ 50.00$. This study will benefit other individuals by providing information that can be used to more accurately determine the body fat levels of active women with menstrual disorders. This study will also benefit the participants involved by providing 
information about their current bone mineral content and body fat levels at no cost to the participant. This information has a market value of $\$ 285.00$.

\section{Precautionary Measures}

I have been informed that if I experience any abnormal symptoms or discomfort while undergoing any of the testing, I should inform the trained personnel administering the test. and they will stop the test immediately.

I give my consent for the release of the information from the lab reports to the investigator. It has further been explained to me that only the investigators will have access to the records and/or data collected for this study, and that all data associated with this study will remain strictly confidential. This information will be used for statistical purposes in order to understand the role of mineral content in estimating body fat levels

Dr. Jacalyn McComb has agreed to answer any inquiries I may have regarding the procedures. I may also contact the Texas Tech University Institutional Review Board for the Protection of Human Subjects by writing them in care of the Office of Research Services, Texas Tech University, Lubbock, Texas, 79409, or by calling 742-3884.

If this research project causes any physical injury to participants in this project. treatment will be supplied in accordance with the participant's insurance. There is not necessarily any treatment available at Texas Tech University, nor do necessarily the University or its personnel applicable to cover any such injury carry any insurance. Financial compensation for any such injury must be provided through the participant $s$ own insurance program. Further information about these matters may be obtained from Dr. Robert M. Sweazy, Vice Provost for Research, (806) 742-3884. Room 203, Holden Hall, Texas Tech University, Lubbock, Texas, 79409-1035.

I understand that I may not derive therapeutic treatment from participation in this study. I understand that I may discontinue this study at any time I choose without penalty.

Signature of Participant

Date

Signature of Project Director or her Authorized Representative:

Date

Signature of Witness to Oral Presentation:

Date 
APPENDIX C

WOMEN`S HEALTH QUESTIONNAIRE 


\section{Women's Health Questionnaire}

We are conducting a study that will benefit women who may have decreased bone mineral content and are interested in obtaining accurate body composition estimations. Your body fat will be assessed by two methods: skinfold equations and hydrostatic weighing. You will also have bone mineral assessments taken. This information will be given to you following the testing. If you are interested in participating in this study: please take a few minutes to complete the questionnaire, and we will tell you if you are eligible to participate in this project. Thank you.

Name: phone \# :

e-mail:

ID\# (Last 4 digits of social security number)

Age:

Birth date:

Height: Weight:

How many years have you been at your present weight?

Have you lost or gained weight recently"?

If you have lost or gained weight recently, how many pounds?

Ethnic background: (Check one)

Caucasian, non-Hispanic

American Indian

Asian Hispanic Black, non- Hispanic Other/specify

If you are an intercollegiate athlete, please check the sport/activity, in which you currently participate, if you are not presently an intercollegiate athlete. please skip to the next question (Check one):

Basketball

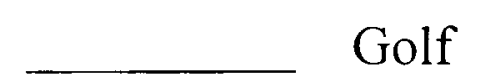

Tennis Track

Softball Other, please specify

Soccer Volleyball

If you play intramural sports, please check the sport/activity in which you currentl! participate. if you do not presently participate in intramural sports, please skip to the next question (Check one):
Basketball
Tennis
Golf
Track
Other, please specify
Soccer
Softball

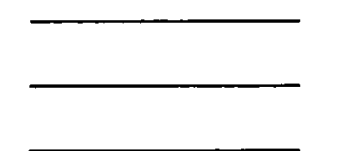

Other, please specify
If you belong to a club sport/activity, please check the sport/activity in which you currently participate, if you do not presently participate in club sports/activities. please skip to the next question (Check one):

Dance Theater

Volleyball Running Water-skiing Cycling Soccer Golf Other, please specify

Please check the type and amount of exercise you usually engage in each weck. Be as specific as possible. for example. weight training 1.5 hours per week: jogging $4 \mathrm{mph}$ for 
1 hour two times a week or aerobics 30 minutes two time a week. or walking $3 \mathrm{mph} 4$ hours each week.

Activity

\#times per week hours per week

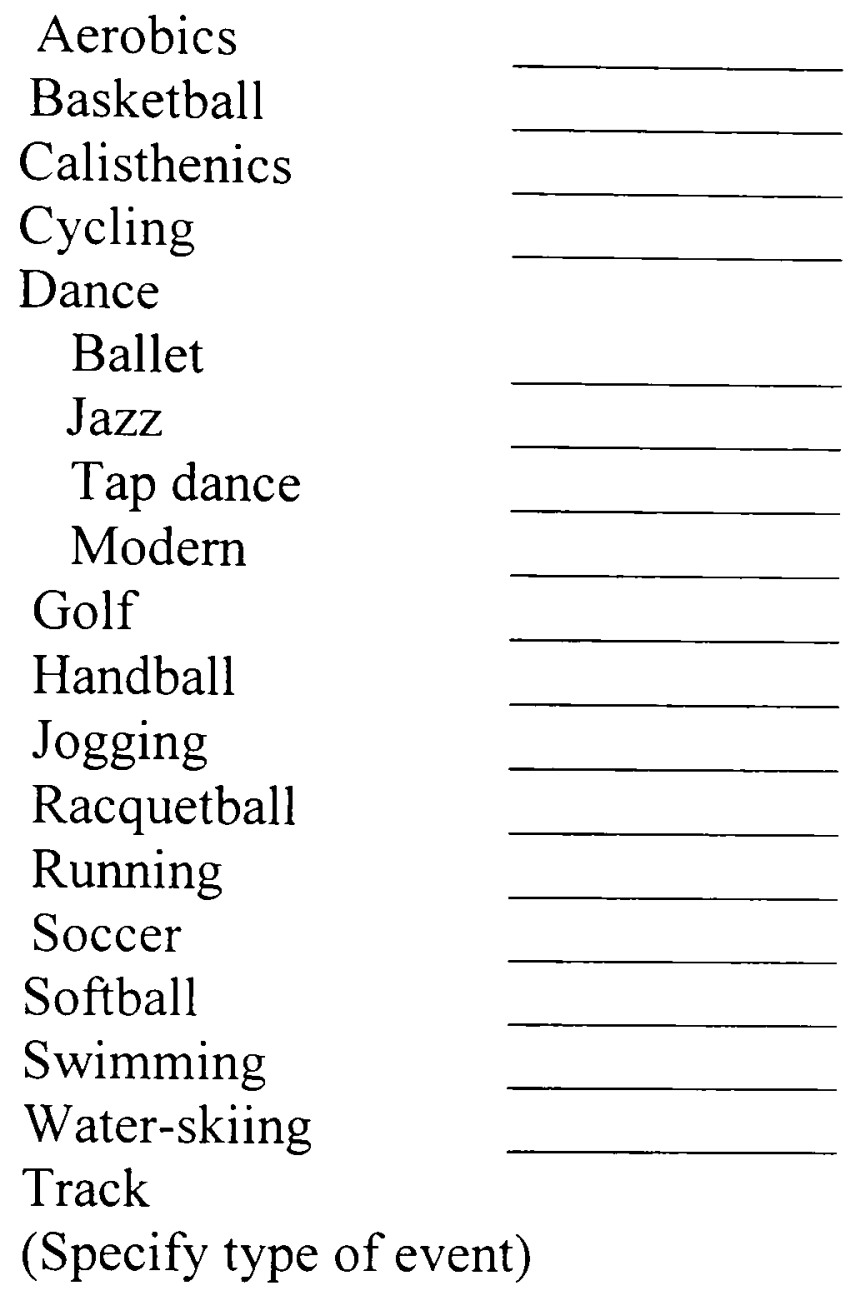

Volleyball

Weight-lifting

Other (list)

$$
\text { applicable) }
$$
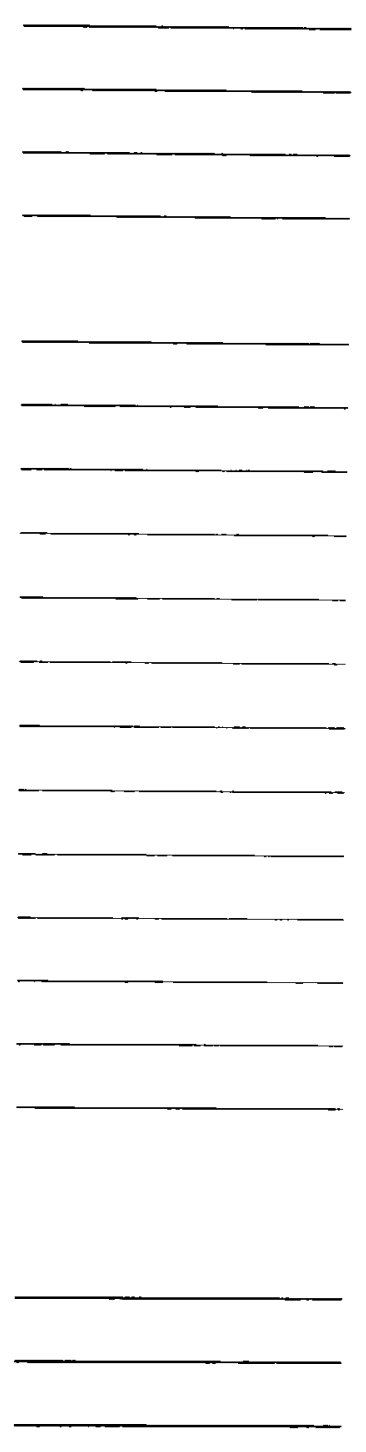

miles per week (if
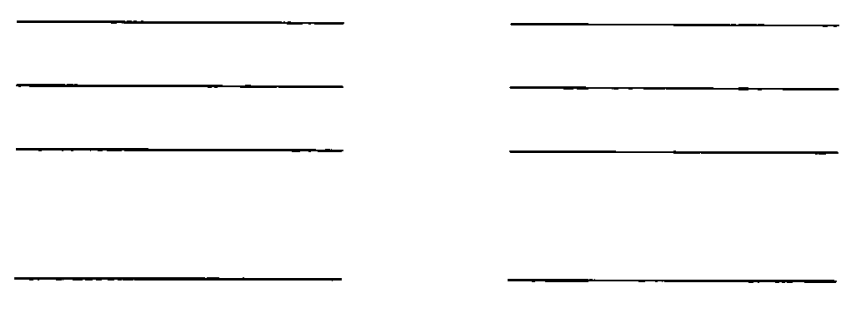

$\overline{\text { How many years (or months) have you been involved in the above activity schedule? }}$ years months

List any injuries you have had or presently have that are related to your participation in these activities.

How is your health? Good

Fair

Poor

Please explain:

Has a health care professional ever told you that you have problems with your thyroid glands?

Yes

No 
Has a health care professional every told you that you had problems with your ovaries? Yes No

Has a health care professional ever told you that you had problems with your uterus? Yes. No

Has a health care professional ever told you that you had problems with your endocrine system? Yes No

Are you now using or have you ever used birth control pills or other hormones (these are used to prevent pregnancy or regulate menstrual periods)?

Yes No

If you have used birth control pills or other hormones, for what reason did you use these? Regulate menstrual periods

Prevent pregnancy

Other reason. Please explain

If you have used birth control pills or other hormones. how long has it been since you used them?

Within the past year, have you taken steroids for any reason (these are occasionally used to reduce inflammation/swelling. etc. during illness or injury)?

Yes No

If you have taken steroids, how long has it been since you took them?

\begin{tabular}{lll}
\hline Are you pregnant? & No \\
Is there a possibility you could be pregnant? & Yes & No \\
Have you recently had a pregnancy test? & Yes & \\
If you answered yes. when was the test? & Dat & No \\
Do you currently smoke? & Yes__ &
\end{tabular}

Would you classify your menstrual cycle as regular?

Or irregular?

Please explain why?

Approximately how many menstrual periods do you have in a year?

Do you experience menstrual bleeding every month?

Do you have a menstrual period every month that is about the same number of days apart from month to month? Yes No 
What was the first day of your last menstrual period? (If you are currently on your menstrual period, please list the first day of your current period).

How many days long was your last menstrual period?

How many days ago was your last menstrual period?

What is the average duration (length in number of days) from the beginning of one menstrual cycle to the beginning of your next menstrual cycle?

How old were you when you first began menses?

Have you ever had or presently have anorexia nervosa or bulimia that you are aware of?

How did you become aware of this? 
APPENDIX D

BODY COMPOSITION DATA COLLECTING SHEET 


\section{Body Composition Data Collecting Sheet}

1. Body Weight in air gms

2. Total weight in water gms

3. Tare weight gms

4. Net weight (2-3) gms

5. Temperature of water ${ }^{\circ} \mathrm{C}$

6. Density of the water

7. Estimated Residual Volume $\mathrm{ml}$

8. Measured Residual Volume $\mathrm{ml}$

9. Total Bone Density $\mathrm{g} / \mathrm{cm}^{2}$

10. $\%$ Fat (Siri)

11. \% Fat (Lohman`s Mineral-Density Equation)

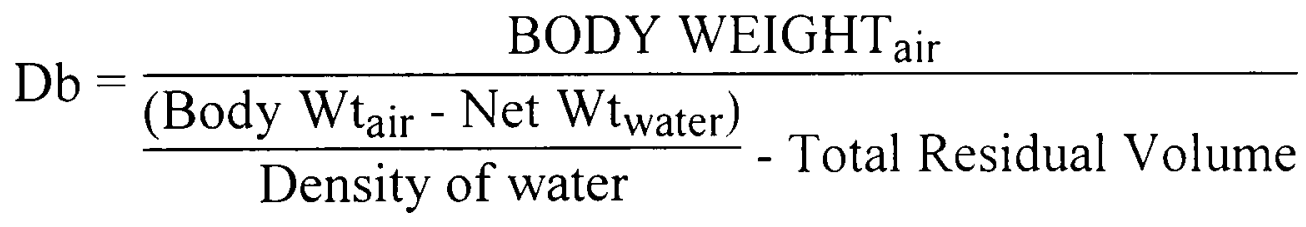

$\mathrm{Db}=$

Siri's Equation (universally accepted)

$\%$ Fat $=4.95 / \mathrm{Db}-4.50 \times 100$

$\%$ Fat $=$

Lohman's Mineral-Density Equation (where $m=$ total bone mineral content)

$\%$ Fat $=(6.386 / \mathrm{Db}+3.961 m-6.090) \times 100$

$\%$ Fat $=$

DEXA Scan Body Fat Computation

$\%$ Fat $=$

$\underline{\text { Results from } 7 \text {-site skinfolds }}$

$\%$ Fat $=$ (see Appendix F) 
APPENDIX E

PULMONARY FUNCTION DATA COLLECTING SHEET 


\section{Pulmonary Function Data Collecting Sheet}

Residual Volume Calculation

Nitrogen in a Bag at equilibration

$\begin{array}{llllll} & 100 \%-\% \mathrm{O}_{2}-\% \mathrm{CO}_{2} & = & \% \text { Nitrogen } \\ \text { Trial 1: } & 100 \%- & - & = & \\ \text { Trial 2: } & 100 \%- & - & = & \\ \text { Trial 3: } & 100 \%- & & \end{array}$

Residual V'olume

Bag Volume $(\mathrm{L}) \times \% \mathrm{~N}_{2} \div\left(79.8-\% \mathrm{~N}_{2}\right)=\mathrm{RV} \quad(\mathrm{L}, \mathrm{ATPS})$

Trial 1:

$\times \square \div(79.8-\square)=$

(L. ATPS)

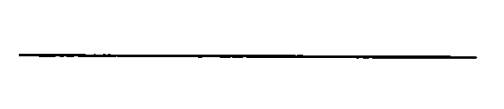

$\div \quad=$

(L, ATPS)

Trial 2:

$$
\times
$$

$$
\div \quad(79.8-
$$

) $=$

(L, ATPS)

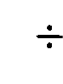

$=$

(L. ATPS)

Trial 3:

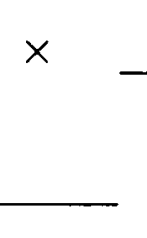

$\div \quad(79.8-$

) $=$

(L. ATPS)

$\div$

$=$

(L. ATPS)

Bag Volume calculation:

$\mathrm{mm} \times 20.73=$
$\mathrm{mm} \times 20.73=$
$\mathrm{mm} \times 20.73=$

(L. ATPS)

(L. ATPS)

(L, ATPS)

BTPS Correlation Factor (BTPS $\mathrm{CF}$ )

$310 \div($ Room Temp +273$) \times\left[\mathrm{P}_{\mathrm{B}}-\left(\mathrm{P}_{220}\right)_{\mathrm{RT}}\right] \div\left[\mathrm{P}_{\mathrm{B}}-\left(\mathrm{P}_{2} \mathrm{O}\right){ }_{\mathrm{BT}}\right]=$ BTPS $_{\mathrm{CF}}$

$310 \div($ $+273) \times[$ $-$ ]$\div[$ $-$

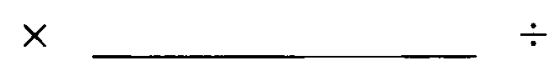
$=$

Measured Residual Volume

${\overline{V_{\text {BTPS }}}}_{=}^{=}{\overline{V_{\text {ATPS }}}}_{\times}^{\times} \overline{\text { BTPS }_{C F}}$ 
APPENDIX F

SKINFOLD DATA COLLECTING SHEET 


\section{Skinfold Data Collecting Sheet}

7-site formula for women

Chest

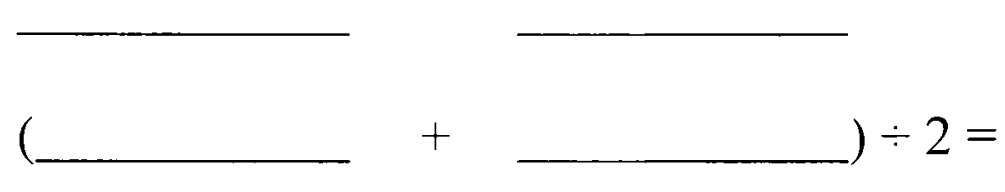

Midaxillary

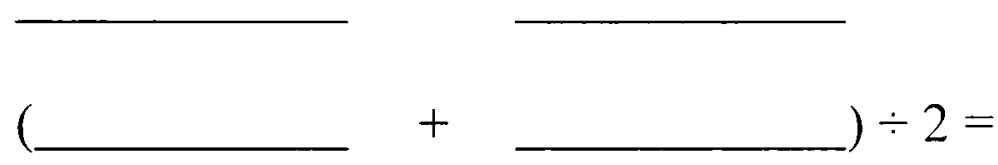

Triceps

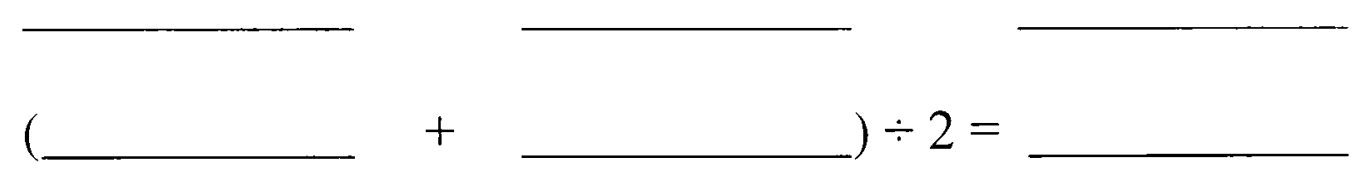

Subscarpular

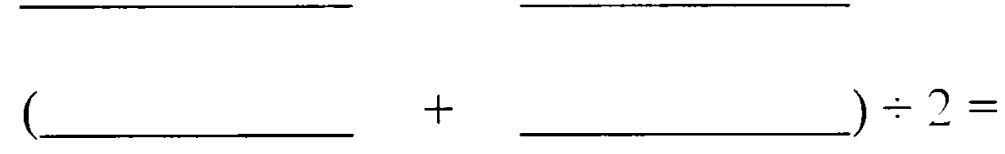

Abdomen

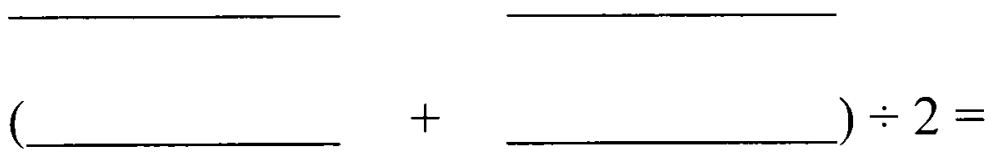

Suprailliac

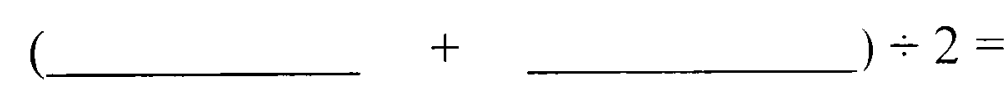

Thigh

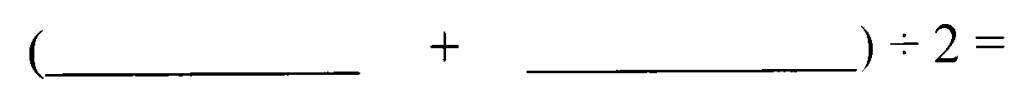

Body density Formula for Women:

$\mathrm{Db}(\mathrm{g} / \mathrm{cc})_{\mathrm{b}}=1.0970-0.00046971\left(\sum 7 \mathrm{SKF}\right)+0.00000056\left(\sum 7 \mathrm{SKF}\right)^{2}-0.00012828($ age $)$

$\mathrm{Db}=$

Siri’s Equation (universally accepted)

$\%$ Fat $=4.95 / \mathrm{Db}-4.50 \times 100$

$\%$ Fat $=$ 


\section{APPENDIX G}

WATER DENSITY FOR VARIOUS WATER TEMERATURES 
Table G.1 Water Density (Dw) for Various Water Temperatures

$\begin{array}{cc}\text { Water Temperature }\left({ }^{\circ} \mathrm{C}\right) & \text { Water Density }(\mathrm{g} / \mathrm{cc}) \\ 4 & 1.00000 \\ 10 & 0.99973 \\ 15 & 0.99913 \\ 20 & 0.99823 \\ 25 & 0.99707 \\ 26 & 0.99681 \\ 27 & 0.99654 \\ 28 & 0.99626 \\ 29 & 0.99595 \\ 30 & 0.99567 \\ 31 & 0.99537 \\ 32 & 0.99505 \\ 33 & 0.99473 \\ 34 & 0.99440 \\ 35 & 0.99406 \\ 36 & 0.99371 \\ 37 & 0.99336 \\ 38 & 0.99299 \\ 39 & 0.99262 \\ 40 & 0.99224\end{array}$

Fox, E. L., Bowers, R. W. \& Foss, M. L. (1989). The physiological basis of physical education and athletics. (4th ed.). Iowa: Wm. C. Brown Publishers. 


\section{APPENDIX H}

WATER VAPOR PRESSURES OF SATURATED AIR AT VARIOUS TEMERATURES 
Table H.1 Water Vapor Pressures of Saturated Air at Various Temperatures

\begin{tabular}{cc}
- Temperature $\left({ }^{\circ} \mathrm{C}\right) \_$Water Vapor Pressure $(\mathrm{mmHg})$ \\
18 & 15.6 \\
19 & 16.55 \\
20 & 17.5 \\
21 & 18.65 \\
22 & 19.8 \\
23 & 21.1 \\
24 & 22.4 \\
25 & 23.8 \\
26 & 25.2 \\
27 & 26.75 \\
28 & 28.3 \\
29 & 30.05 \\
30 & 31.8 \\
37 & 47.1 \\
\hline
\end{tabular}




\section{APPENDIX I}

\section{REPEATED ONE-WAY ANALYSIS OF VARIANCE}




\title{
Table I.1
}

Repeated One-Way Analysis of Variance

Within-Subjects Factors

BODYFAT
1
2
3
4

\author{
Dependent Variable \\ SKFFATSI \\ HWFATSI \\ HWFATLOH3 \\ DEXAFAT
}
Note: SKFFATSI $=\%$ fat from 7-site skinfolds using Siri ${ }^{\text {s }}$ equation HWFATSI $=\%$ fat from HW with Siri's equation
HWFATLOH $3=\%$ fat from with Lohman's bone mineral equation DEXAFAT $=\%$ fat from DEXA

Descriptive Statistics

\begin{tabular}{cccc} 
& Mean & Std. Deviation & $\mathrm{N}$ \\
SKFFATSI & 16.1130 & 2.7786 & 10 \\
HWFATSI & 23.6300 & 3.7505 & 10 \\
HWFATLOH3 & 17.1320 & 5.6672 & 10 \\
DEXAFAT & 26.8200 & 8.1697 & 10 \\
\hline
\end{tabular}

Tests of Within-Subjects Effects

\begin{tabular}{|c|c|c|c|c|c|c|c|}
\hline Source & & $\begin{array}{l}\text { Type III Sum of } \\
\text { Squares }\end{array}$ & df & Mean Square & $\mathrm{F}$ & Sig. & Eta Squared \\
\hline \multirow[t]{4}{*}{ BODYFAT } & $\begin{array}{l}\text { Sphericity } \\
\text { Assumed }\end{array}$ & 796.102 & 3 & 265.367 & 26.889 & .000 & .749 \\
\hline & $\begin{array}{l}\text { Greenhouse- } \\
\text { Geisser }\end{array}$ & 796.102 & 1.718 & 463.286 & 26.889 & .000 & .749 \\
\hline & Huynh-Feldt & 796.102 & 2.085 & 381.783 & 26.889 & .000 & $7+9$ \\
\hline & Lower-bound & 796.102 & 1.000 & 796.102 & 26.889 & .001 & 749 \\
\hline \multirow[t]{4}{*}{$\begin{array}{c}\text { Error } \\
\text { (BODYFAT) }\end{array}$} & $\begin{array}{l}\text { Sphericity } \\
\text { Assumed }\end{array}$ & 266.458 & 27 & 9.869 & & & \\
\hline & $\begin{array}{l}\text { Greenhouse- } \\
\text { Geisser }\end{array}$ & 266.458 & 15.465 & 17.229 & & & \\
\hline & Huynh-Feldt & 266.458 & 18.767 & 14.198 & & & \\
\hline & Lower-bound & 266.458 & 9.000 & 29.606 & & & \\
\hline
\end{tabular}


APPENDIX J

PAIRED SAMPLE T-TEST 
Table J.1

Paired Samples Statistics

Paired Sample T-Test

$\begin{array}{cccccc} & & \text { Mean } & \mathrm{N} & \text { Std. Deviation } & \text { Std. Error Mean } \\ \text { Pair 1 } & \text { SKFFATSI } & 16.1130 & 10 & 2.7786 & .8787 \\ & \text { HWFATSI } & 23.6300 & 10 & 3.7505 & 1.1860 \\ \text { Pair 2 } & \text { SKFFATSI } & 16.1130 & 10 & 2.7786 & .8787 \\ & \text { HWFATLOH3 } & 17.1320 & 10 & 5.6672 & 1.7921 \\ \text { Pair 3 } & \text { SKFFATSI } & 16.1130 & 10 & 2.7786 & .8787 \\ & \text { DEXAFAT } & 26.8200 & 10 & 8.1697 & 2.5835 \\ \text { Pair 4 } & \text { HWFATSI } & 23.6300 & 10 & 3.7505 & 1.1860 \\ & \text { HWFATLOH3 } & 17.1320 & 10 & 5.6672 & 1.7921 \\ \text { Pair 5 } & \text { HWFATSI } & 23.6300 & 10 & 3.7505 & 1.1860 \\ & \text { DEXAFAT } & 26.8200 & 10 & 8.1697 & 2.5835 \\ \text { Pair 6 } & \text { HWFATLOH3 } & 17.1320 & 10 & 5.6672 & 1.7921 \\ & \text { DEXAFAT } & 26.8200 & 10 & 8.1697 & 2.5835\end{array}$

Paired Samples Correlations

$\begin{array}{lcccc} & & \text { N } & \text { Correlation } & \text { Sig. } \\ \text { Pair 1 } & \text { SKFFATSI \& HWFATSI } & 10 & .719 & .019 \\ \text { Pair 2 } & \text { SKFFATSI \& HWFATLOH3 } & 10 & .548 & .101 \\ \text { Pair 3 } & \text { SKFFATSI \& DEXAFAT } & 10 & .794 & .006 \\ \text { Pair 4 } & \text { HWFATSI \& HWFATLOH3 } & 10 & .954 & .000 \\ \text { Pair 5 } & \text { HWFATSI \& DEXAFAT } & 10 & .912 & .000 \\ \text { Pair 6 } & \text { HWFATLOH3 \& DEXAFAT } & 10 & .851 & .002\end{array}$

Paired Samples Test

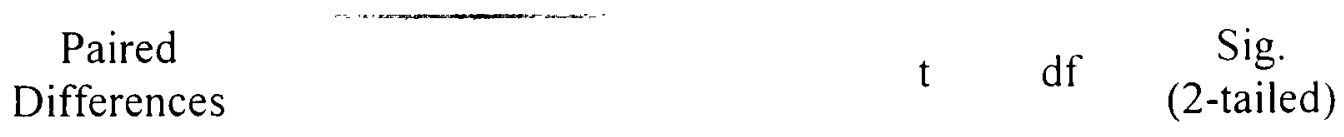

\begin{tabular}{|c|c|c|c|c|c|c|c|}
\hline & & Mean & Std. Deviation & $\begin{array}{l}\text { Std. Error } \\
\text { Mean }\end{array}$ & & & \\
\hline Pair 1 & $\begin{array}{c}\text { SKFFATSI - } \\
\text { HWFATSI }\end{array}$ & -7.5170 & 2.6079 & .8247 & -9.115 & 9 & .000 \\
\hline Pair 2 & $\begin{array}{l}\text { SKFFATSI - } \\
\text { HWFATLOH3 }\end{array}$ & -1.0190 & 4.7507 & 1.5023 & .678 & 9 & .515 \\
\hline Pair 3 & $\begin{array}{l}\text { SKFFAT - } \\
\text { DEXAFAT }\end{array}$ & -10.7070 & 6.1972 & 1.9597 & -5.464 & 9 & .000 \\
\hline Pair 4 & $\begin{array}{l}\text { HWFATSI - } \\
\text { HWFATLOH3 }\end{array}$ & 6.4980 & 2.3764 & .7515 & 8.647 & 9 & .000 \\
\hline Pair 5 & $\begin{array}{l}\text { HWFATSI - } \\
\text { DEXAFAT }\end{array}$ & -3.1900 & 4.9936 & 1.5791 & -2.020 & 9 & .074 \\
\hline Pair 6 & $\begin{array}{l}\text { HWFATLOH3- } \\
\text { DEXAFAT }\end{array}$ & -9.6880 & 4.4796 & 1.4166 & -6.839 & 9 & .000 \\
\hline
\end{tabular}




\section{APPENDIX K}

RELATIONSHIP OF BODY DENSITY WITH BMD, BMC, 2-COMPONENT AND 3-COMPONENT MODELS 


\section{Table K.1}

\section{Relationship of $\mathrm{Db}$ with Bone Mineral Density. Bone Mineral Content, 2-Component.}

and 3-Component Models $(\mathrm{N}=10)$

\begin{tabular}{|c|c|c|c|c|c|c|c|c|}
\hline & & $\mathrm{Db}$ & BMD & BMC & $\begin{array}{r}\text { SKF } \\
\text { FATSI }\end{array}$ & $\begin{array}{r}\text { HWFAT } \\
\text { SI }\end{array}$ & $\begin{array}{r}\text { HWFAT } \\
\text { LOH3 }\end{array}$ & $\begin{array}{r}\text { DEXA } \\
\text { FAT }\end{array}$ \\
\hline \multirow[t]{2}{*}{$\mathrm{Db}$} & $\begin{array}{r}\text { Pearson } \\
\text { Correlation }\end{array}$ & 1.000 & -.441 & -.236 & -.598 & $-.981 * *$ & $-.988 * *$ & $-.870 * *$ \\
\hline & Sig. (2-tailed) & ${ }^{\circ}$ & .202 & .512 & .068 & .000 & .000 & .00 \\
\hline \multirow[t]{2}{*}{ BMD } & $\begin{array}{r}\text { Pearson } \\
\text { Correlation }\end{array}$ & -.441 & 1.000 & $.956^{* *}$ & $.668^{*}$ & .521 & 465 & .75 \\
\hline & Sig. (2-tailed) & .202 & . & .000 & .035 & .123 & .176 & .01 \\
\hline \multirow[t]{2}{*}{ BMC } & $\begin{array}{r}\text { Pearson } \\
\text { Correlation }\end{array}$ & -.236 & $.956 * *$ & 1.000 & $.665^{*}$ & .349 & .249 & .6 \\
\hline & Sig. (2-tailed) & .512 & .000 & . & .036 & .323 & .488 & .05 \\
\hline \multirow[t]{2}{*}{$\begin{array}{l}\text { SKFFAT } \\
\text { SI }\end{array}$} & $\begin{array}{r}\text { Pearson } \\
\text { Correlation }\end{array}$ & -.598 & $.668^{*}$ & $.665^{*}$ & 1.000 & $.719^{*}$ & .548 & .794 \\
\hline & Sig. (2-tailed) & .068 & .035 & .036 & & .019 & .101 & .0 \\
\hline \multirow[t]{2}{*}{ HWFATSI } & $\begin{array}{r}\text { Pearson } \\
\text { Correlation }\end{array}$ & $-.981^{* *}$ & .521 & .349 & $.719^{*}$ & 1.000 & .954 & .912 \\
\hline & Sig. (2-tailed) & .000 & .123 & .323 & .019 & & .000 & .00 \\
\hline \multirow[t]{2}{*}{$\begin{array}{r}\text { HWFAT } \\
\text { LOH3 }\end{array}$} & $\begin{array}{r}\text { Pearson } \\
\text { Correlation }\end{array}$ & $-.988 * *$ & .465 & .249 & .548 & $.954^{* *}$ & 1.000 & .8 \\
\hline & Sig. (2-tailed) & .000 & .176 & .488 & .101 & .000 & & .002 \\
\hline \multirow[t]{2}{*}{$\begin{array}{r}\text { DEXA } \\
\text { FAT }\end{array}$} & $\begin{array}{r}\text { Pearson } \\
\text { Correlation }\end{array}$ & $-.870 * *$ & $.755^{*}$ & .630 & $.794 * *$ & $.912 * *$ & $.851 * *$ & 1.00 \\
\hline & Sig. (2-tailed) & .001 & .012 & .051 & .006 & .000 & .002 & \\
\hline
\end{tabular}

** Correlation is significant at the 0.01 level (2-tailed).

* Correlation is significant at the 0.05 level (2-tailed).

Note: $\mathrm{Db}=$ body density

$\mathrm{BMD}=$ bone mineral densit

$\mathrm{BMC}=$ bone mineral content

SKFFATSI $=7$-site skinfolds ${ }^{\circ}$ ofat

HWFATSI $=$ underwater weight ${ }^{\circ}$ ofat with Siri's equation

HWFATLOH3 = underwater weight \%fat with Lohman's bone mineral equation

DEXAFAT $=\%$ fat from DEXA 


\section{APPENDIX L}

\section{REPEATED MEASUREMENTS WITH 6 LEVELS}


Table L.1

Repeated Measurements with 6 Levels

Within-Subjects Factors

Measure: MEASURE 1

$\begin{array}{cc}\text { LEVELS } & \text { Dependent Variable } \\ 1 & \text { SKFFATSI } \\ 2 & \text { HWFATSI } \\ 3 & \text { HWFATLOH3 } \\ 4 & \text { DEXAFAT } \\ 5 & \text { SKFFATLO } \\ 6 & \text { HWLOH2 }\end{array}$

Note: SKFFATSI $=\%$ fat from 7-site skinfolds using Siri's equation (2-Component Model)

HWFATSI $=\%$ fat from HW using Siri's equation (2-Component Model)

HWFATLOH3 $=\%$ fat from HW using Lohman's equation (3-Component Model)

DEXAFAT $=\%$ fat from DEXA (3-Component Model)

SKFFATLO $=\%$ fat from 7-site skinfolds using Lohman's equation (2-Component Model)

$\mathrm{HWLOH} 2=\%$ fat from HW using Lohman's equation (2-Component Model)

Descriptive Statistics

$\begin{array}{cccc} & \text { Mean } & \text { Std. Deviation } & \mathrm{N} \\ \text { SKFFAT } & 16.1130 & 2.7786 & 10 \\ \text { HWFATSI } & 23.6300 & 3.7505 & 10 \\ \text { HWFATLOH } & 17.1320 & 5.6672 & 10 \\ \text { DEXAFAT } & 26.8200 & 8.1697 & 10 \\ \text { SKFFATLO } & 14.2940 & 2.8546 & 10 \\ \text { HWLOH2 } & 21.1910 & 4.9201 & 10\end{array}$

Tests of Within-Subjects Effects

Measure: MEASURE_1

\begin{tabular}{ccccccc}
\hline Source & & Type III Sum of Squares & df & Mean Square & F & Sig. \\
\hline LEVELS & Sphericity Assumed & 1168.883 & 5 & 233.777 & 29.161 & .000 \\
& Greenhouse-Geisser & 1168.883 & 1.765 & 662.381 & 29.161 & .000 \\
& Huynh-Feldt & 1168.883 & 2.163 & 540.514 & 29.161 & .000 \\
& Lower-bound & 1168.883 & 1.000 & 1168.883 & 29.161 & .000 \\
Error (LEVELS) & Sphericity Assumed & 360.754 & 45 & 8.017 & & \\
& Greenhouse-Geisser & 360.754 & 15.882 & 22.715 & & \\
& Huynh-Feldt & 360.754 & 19.463 & 18.535 & & \\
& Lower-bound & 360.754 & 9.000 & 40.084 & &
\end{tabular}




\section{APPENDIX M}

\section{PAIRED SAMPLE T-TEST WITH 6 LEVELS}


Table M.1

Paired Samples Statistics

Paired Sample T-Test with 6 Levels

\begin{tabular}{|c|c|c|c|c|c|}
\hline & & Mean & $\mathrm{N}$ & Std. Deviation & Std. Error Mean \\
\hline \multirow[t]{2}{*}{ Pair 1} & SKFFATSI & 16.1130 & 10 & 2.7786 & .8787 \\
\hline & HWFATSI & 23.6300 & 10 & 3.7505 & 1.1860 \\
\hline \multirow[t]{2}{*}{ Pair 2} & SKFFATSI & 16.1130 & 10 & 2.7786 & .8787 \\
\hline & HWFATLOH3 & 17.1320 & 10 & 5.6672 & 1.7921 \\
\hline \multirow[t]{2}{*}{ Pair 3} & SKFFATSI & 16.1130 & 10 & 2.7786 & .8787 \\
\hline & DEXAFAT & 26.8200 & 10 & 8.1697 & 2.5835 \\
\hline \multirow[t]{2}{*}{ Pair 4} & SKFFATSI & 16.1130 & 10 & 2.7786 & .8787 \\
\hline & SKFFATLO & 14.2940 & 10 & 2.8546 & .9027 \\
\hline \multirow[t]{2}{*}{ Pair 5} & SKFFATSI & 16.1130 & 10 & 2.7786 & .8787 \\
\hline & HWLOH2 & 21.1910 & 10 & 4.9201 & 1.5559 \\
\hline \multirow[t]{2}{*}{ Pair 6} & HWFATSI & 23.6300 & 10 & 3.7505 & 1.1860 \\
\hline & HWFATLOH3 & 17.1320 & 10 & 5.6672 & 1.7921 \\
\hline \multirow[t]{2}{*}{ Pair 7} & HWFATSI & 23.6300 & 10 & 3.7505 & 1.1860 \\
\hline & DEXAFAT & 26.8200 & 10 & 8.1697 & 2.5835 \\
\hline \multirow[t]{2}{*}{ Pair 8} & HWFATSI & 23.6300 & 10 & 3.7505 & 1.1860 \\
\hline & SKFFATLO & 14.2940 & 10 & 2.8546 & .9027 \\
\hline \multirow[t]{2}{*}{ Pair 9} & HWFATSI & 23.6300 & 10 & 3.7505 & 1.1860 \\
\hline & HWLOH2 & 21.1910 & 10 & 4.9201 & 1.5559 \\
\hline \multirow[t]{2}{*}{ Pair 10} & HWFATLOH3 & 17.1320 & 10 & 5.6672 & 1.7921 \\
\hline & DEXAFAT & 26.8200 & 10 & 8.1697 & 2.5835 \\
\hline \multirow[t]{2}{*}{ Pair 11} & HWFATLOH3 & 17.1320 & 10 & 5.6672 & 1.7921 \\
\hline & SKFFATLO & 14.2940 & 10 & 2.8546 & .9027 \\
\hline \multirow[t]{2}{*}{ Pair 12} & HWFATLOH3 & 17.1320 & 10 & 5.6672 & 1.7921 \\
\hline & HWLOH2 & 21.1910 & 10 & 4.9201 & 1.5559 \\
\hline \multirow[t]{2}{*}{ Pair 13} & DEXAFAT & 26.8200 & 10 & 8.1697 & 2.5835 \\
\hline & SKFFATLO & 14.2940 & 10 & 2.8546 & .9027 \\
\hline \multirow[t]{2}{*}{ Pair 14} & DEXAFAT & 26.8200 & 10 & 8.1697 & 2.5835 \\
\hline & HWLOH2 & 21.1910 & 10 & 4.9201 & 1.5559 \\
\hline \multirow[t]{2}{*}{ Pair 15} & SKFFATLO & 14.2940 & 10 & 2.8546 & .9027 \\
\hline & HWLOH2 & 21.1910 & 10 & 4.9201 & 1.5559 \\
\hline
\end{tabular}

Note: SKFFATSI $=\%$ fat from 7-site skinfolds using Siri's equation (2-Component Model)

HWFATSI $=\%$ fat from HW using Siri's equation (2-Component Model)

HWFATLOH $=\%$ fat from HW using Lohman's equation (3-Component Model)

DEXAFAT $=\%$ fat from DEXA (3-Component Model)

SKFFATLO $=\%$ fat from 7-site skinfolds using Lohman's equation (2-Component Model)

$\mathrm{HWLOH} 2=\%$ fat from HW using Lohman's equation (2-Component Model) 
Table M.1. Continued.

Paired Samples Correlations

\begin{tabular}{|c|c|c|c|c|}
\hline & & $\mathrm{N}$ & Correlation & Sig. \\
\hline Pair 1 & SKFFATSI \& HWFATSI & 10 & .719 & .019 \\
\hline Pair 2 & SKFFATSI \& HWFATLOH3 & 10 & .548 & .101 \\
\hline Pair 3 & SKFFATSI \& DEXAFAT & 10 & .794 & .006 \\
\hline Pair 4 & SKFFATSI \& SKFFATLO & 10 & 1.000 & .000 \\
\hline Pair 5 & SKFFATSI \& HWLOH2 & 10 & .603 & .065 \\
\hline Pair 6 & HWFATSI \& HWFATLOH3 & 10 & .954 & .000 \\
\hline Pair 7 & HWFATSI \& DEXAFAT & 10 & .912 & .000 \\
\hline Pair 8 & HWFATSI \& SKFFATLO & 10 & .720 & .019 \\
\hline Pair 9 & HWFATSI \& HWLOH2 & 10 & .982 & .000 \\
\hline Pair 10 & HWFATLOH3 \& DEXAFAT & 10 & .851 & .002 \\
\hline Pair 11 & HWFATLOH3 \& SKFFATLO & 10 & .549 & .100 \\
\hline Pair 12 & HWFATLOH3 \& HWLOH2 & 10 & .987 & .000 \\
\hline Pair 13 & DEXAFAT \& SKFFATLO & 10 & .795 & .006 \\
\hline Pair 14 & DEXAFAT \& HWLOH2 & 10 & .873 & .001 \\
\hline Pair 15 & SKFFATLO \& HWLOH2 & 10 & .604 & .065 \\
\hline
\end{tabular}

Note: SKFFATSI $=\%$ fat from 7 -site skinfolds using Siri's equation (2-Component Model)

HWFATSI $=\%$ fat from HW using Siri's equation (2-Component Model)

HWFATLOH $3=\%$ fat from HW using Lohman's equation (3-Component Model)

DEXAFAT $=\%$ fat from DEXA (3-Component Model)

SKFFATLO $=\%$ fat from 7-site skinfolds using Lohman's equation (2-Component Model)

$\mathrm{HWLOH} 2=\%$ fat from HW using Lohman's equation (2-Component Model) 
Table M.1. Continued.

Paired Samples Test

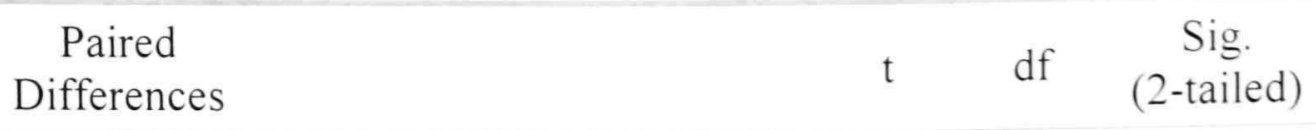

$$
\text { Mean Std. Deviation } \begin{gathered}
\text { Std. Error } \\
\text { Mean }
\end{gathered}
$$

\begin{tabular}{|c|c|c|c|c|c|c|c|}
\hline Pair 1 & $\begin{array}{c}\text { SKFFATSI - } \\
\text { HWFATSI }\end{array}$ & -7.5170 & 2.6079 & .8247 & -9.115 & 9 & .000 \\
\hline Pair 2 & $\begin{array}{l}\text { SKFFATSI - } \\
\text { HWFATLOH3 }\end{array}$ & -1.0190 & 4.7507 & 1.5023 & -.678 & 9 & .515 \\
\hline Pair 3 & $\begin{array}{l}\text { SKFFATSI - } \\
\text { DEXAFAT }\end{array}$ & -10.7070 & 6.1972 & 1.9597 & -5.464 & 9 & .000 \\
\hline Pair 4 & $\begin{array}{l}\text { SKFFATSI - } \\
\text { SKFFATLO }\end{array}$ & 1.8190 & $7.622 \mathrm{E}-02$ & $2.410 \mathrm{E}-02$ & 75.465 & 9 & .000 \\
\hline Pair 5 & $\begin{array}{c}\text { SKFFATSI - } \\
\text { HWLOH2 }\end{array}$ & -5.0780 & 3.9292 & 1.2425 & -4.087 & 9 & .003 \\
\hline Pair 6 & $\begin{array}{l}\text { HWFATSI - } \\
\text { HWFATLOH3 }\end{array}$ & 6.4980 & 2.3764 & .7515 & 8.647 & 9 & .000 \\
\hline Pair 7 & $\begin{array}{l}\text { HWFATSI - } \\
\text { DEXAFAT }\end{array}$ & -3.1900 & 4.9936 & 1.5791 & -2.020 & 9 & .074 \\
\hline Pair 8 & $\begin{array}{l}\text { HWFATSI - } \\
\text { SKFFATLO }\end{array}$ & 9.3360 & 2.6093 & .8251 & 11.315 & 9 & .000 \\
\hline Pair 9 & $\begin{array}{c}\text { HWFATSI - } \\
\text { HWLOH2 }\end{array}$ & 2.4390 & 1.4239 & .4503 & 5.417 & 9 & .000 \\
\hline Pair 10 & $\begin{array}{c}\text { HWFATLOH3 - } \\
\text { DEXAFAT }\end{array}$ & -9.6880 & 4.4796 & 1.4166 & -6.839 & 9 & .000 \\
\hline Pair 11 & $\begin{array}{c}\text { HWFATLOH3 - } \\
\text { SKFFATLO }\end{array}$ & 2.8380 & 4.7443 & 1.5003 & 1.892 & 9 & .091 \\
\hline Pair 12 & $\begin{array}{c}\text { HWFATLOH3 - } \\
\text { HWLOH2 }\end{array}$ & -4.0590 & 1.1289 & .3570 & -11.370 & 9 & .000 \\
\hline Pair 13 & $\begin{array}{l}\text { DEXAFAT - } \\
\text { SKFFATLO }\end{array}$ & 12.5260 & 6.1490 & 1.9445 & 6.442 & 9 & .000 \\
\hline Pair 14 & $\begin{array}{c}\text { DEXAFAT - } \\
\text { HWLOH2 }\end{array}$ & 5.6290 & 4.5610 & 1.4423 & 3.903 & 9 & .004 \\
\hline Pair 15 & $\begin{array}{c}\text { SKFFATLO - } \\
\text { HWLOH2 }\end{array}$ & -6.8970 & 3.9244 & 1.2410 & -5.558 & 9 & .000 \\
\hline
\end{tabular}




\section{PERMISSION TO COPY}

In presenting this thesis in partial fulfillment of the requirements for a master's degree at Texas Tech University or Texas Tech University Health Sciences Center, I agree that the Library and my major department shall make it freely available for research purposes. Permission to copy this thesis for scholarly purposes may be granted by the Director of the Library or my major professor. It is understood that any copying or publication of this thesis for financial gain shall not be allowed without my further written permission and that any user may be liable for copyright infringement.

Agree (Permission is granted.)

Disagree (Permission is not granted.) 